\title{
Growth and demise of Permian biogenic chert along northwest Pangea: evidence for end-Permian collapse of thermohaline circulation
}

\author{
Benoit Beauchamp ${ }^{\mathrm{a}, *}$, Aymon Baud ${ }^{\mathrm{b}}$ \\ a Geological Survey of Canada, 3303, 33rd ST NW, Calgary, AB, Canada T2L $2 A 7$ \\ b Musée cantonal de géologie, CH-1015 Lausanne, Switzerland
}

Received 1 March 2001; accepted 1 February 2002

\begin{abstract}
The Permian Chert Event (PCE) was a $30 \mathrm{Ma}$ long episode of unusual chert accumulation along the northwest margin of Pangea, and possibly worldwide. The onset of the PCE occurred at about the Sakmarian-Artinskian boundary in the Sverdrup Basin, Canadian Arctic, where it coincides with a maximum flooding event, the ending of high-frequency/high-amplitude shelf cyclicity, the onset of massive biogenic chert deposition in deep-water distal areas, and a long-term shift from warm- to cool-water carbonate sedimentation in shallow-water proximal areas. A similar and coeval shift is observed from the Barents Sea to the northwestern USA. A landward and southward expansion of silica factories occurred during the Middle and Late Permian at which time warm-water carbonate producers disappeared completely from the northwest margin of Pangea. Biotically impoverished and increasingly narrow cold-water carbonate factories (characterised by non-cemented bioclasts of sponges, bryozoans, echinoderms and brachiopods) were then progressively replaced by silica factories. By Late Permian time, little carbonate sediments accumulated in the Barents Sea and in the Sverdrup Basin, where the deep- to shallow-water sedimentary spectrum was occupied by siliceous sponge spicules. By that time, biogenic silica sedimentation was common throughout the world. Silica factories collapsed in the Late Permian, abruptly bringing the PCE to an end. In northwest Pangea, the end-Permian collapse of the PCE was associated with a major transgression and with a return to much warmer oceanic and continental climatic conditions. Chert deposition resumed in the distal oceanic areas during the early Middle Triassic (Anisian) after a 8-10 Ma interruption (Early Triassic Chert Gap). The conditions necessary for the onset, expansion and zenith of the PCE were provided by the thermohaline circulation of nutrient-rich cold waters along the northwestern and western margin of Pangea, and possibly throughout the world oceans. These conditions provided an efficient transportation mechanism that constantly replenished the supply of silica in the area, created a nutrient- and oxygen-rich environment favouring siliceous biogenic productivity, established cold sea-floor conditions, hindering silica dissolution, while increasing calcium carbonate solubility, and provided conditions adverse to organic and inorganic carbonate production. The northwest margin of Pangea was, for nearly $30 \mathrm{Ma}$, bathed by cold waters presumably derived from the seasonal melting of northern sea ice, the assumed engine for thermohaline circulation.
\end{abstract}


This process started near the Sakmarian-Artinskian boundary, intensified throughout Middle and Late Permian time and ceased suddenly in latest Permian time. It led to oceanic conditions much colder than normally expected from the palaeolatitudes, and the influence of cold northerly-derived water was felt as far south southern Nevada. The demise of silica factories was caused by the rapid breakdown of these conditions and the establishment of a much warmer marine environment accompanied by sluggish circulation and perhaps a reduced input of dissolved silica to the ocean. Complete thawing of northern sea ice would have ended thermohaline circulation and led to warm and sluggish oceanic conditions inimical to the production, accumulation and preservation of biogenic silica. (C) 2002 Elsevier Science B.V. All rights reserved.

Keywords: chert; carbonate; Permian; Triassic; Pangea; cooling; thermohaline

\section{Introduction}

The end-Permian extinction and associated environmental turnover has received much attention in the literature over the past decade (see summaries by Erwin, 1993, 1994, 1995), an interest fueled by the $\mathrm{K}-\mathrm{T}$ boundary extinction and the extraterrestrial bolide hypothesis (Alvarez et al., 1980). Collision with a speeding interplanetary projectile (Xu et al., 1985; Xu and Yan, 1993; Retallack et al., 1998; Becker et al., 2001; Kaiho et al., 2001) is but one of numerous causes that have been invoked to explain the end-Permian devastation. Of particular interest are the purported changes to the global oceanic circulation system leading to, or accompanying, the end-Permian event. Diametrically-opposed views have been expressed in the literature. For instance, it has been suggested that the Permian was a time of increasingly sluggish thermohaline circulation (Keith, 1982; Herring, 1995), leading to increasingly oxygen-deficient, and ultimately anoxic, bottom waters, the rapid and presumably global overturn of which contributed to the extinction event (Kajiwara et al., 1994; Knoll et al., 1996; Suzuki et al., 1998). In contrast, it has been proposed that most of the Permian was a time of well-oxygenated thermohaline circulation (Isozaki, 1994, 1997), the demise of which led to a worldwide anoxic event during the Lopingian with global anoxia spreading from deep to shallow environments and extending well into the Early Triassic (Wignall and Hallam, 1992; Wignall et al., 1998).

The goal of this paper is to present evidence that thermohaline oceanic circulation was vigorous along the margins of Pangea during the Per- mian yet sluggish during the Early Triassic. This evidence is based on the widespread occurrence of Permian biogenic cherts regionally and the absence of Early Triassic cherts globally. This paper builds and expands from the contributions of Beauchamp (1994), who first documented the Permian cooling trend along the northwest margin of Pangea, and Beauchamp and Desrochers (1997), who described and interpreted the range of warm to cold Permian carbonate and chert facies associated with the cooling trend. Both of these contributions suggested that oceanic circulation may have played a major role in the observed cooling, an idea also examined recently by Mei and Henderson (2001) to explain the distribution of conodont fauna. This theme is further developed here.

\section{Permian Chert Event (PCE) and Early Triassic Chert Gap (ETCG)}

Some episodes of Earth's history have been more favourable to chert formation than others (Hein and Parrish, 1987; Maliva et al., 1990). The term 'burb', as in the 'Eocene Silica Burb' (McGowran, 1989), or the term 'event', as in the 'Permian Chert Event' (Murchey and Jones, 1992), have been used to label some of these episodes when biogenic silica appears to have been produced faster and/or preserved more efficiently than during other periods. Likewise, there were times when very little, if any, biogenic chert was produced and/or preserved. The 8-10 Ma long Early Triassic 'Chert Gap' is one of such events (Casey, 1993; Kakuwa, 1996; Kozur, 1998a,b; Racki, 1999). 


\subsection{Prior to PCE: Sakmarian and earlier}

For most of the Carboniferous period, and up until the Sakmarian (mid Early Permian), biogenic silica factories existed along the northwest margin of Pangea, occurring in distal, deep-water, slope to basinal areas adjacent to productive car- bonate factories. While biogenic silica production was high during this interval, spiculitic and radiolarian deep-water deposits are not necessarily preserved as chert, but rather as a vast array of cherty carbonates and mudrocks. Examples of such deposits include: the Kuna and Tupik formations and the Akmalik and Imnaitchiak forma-

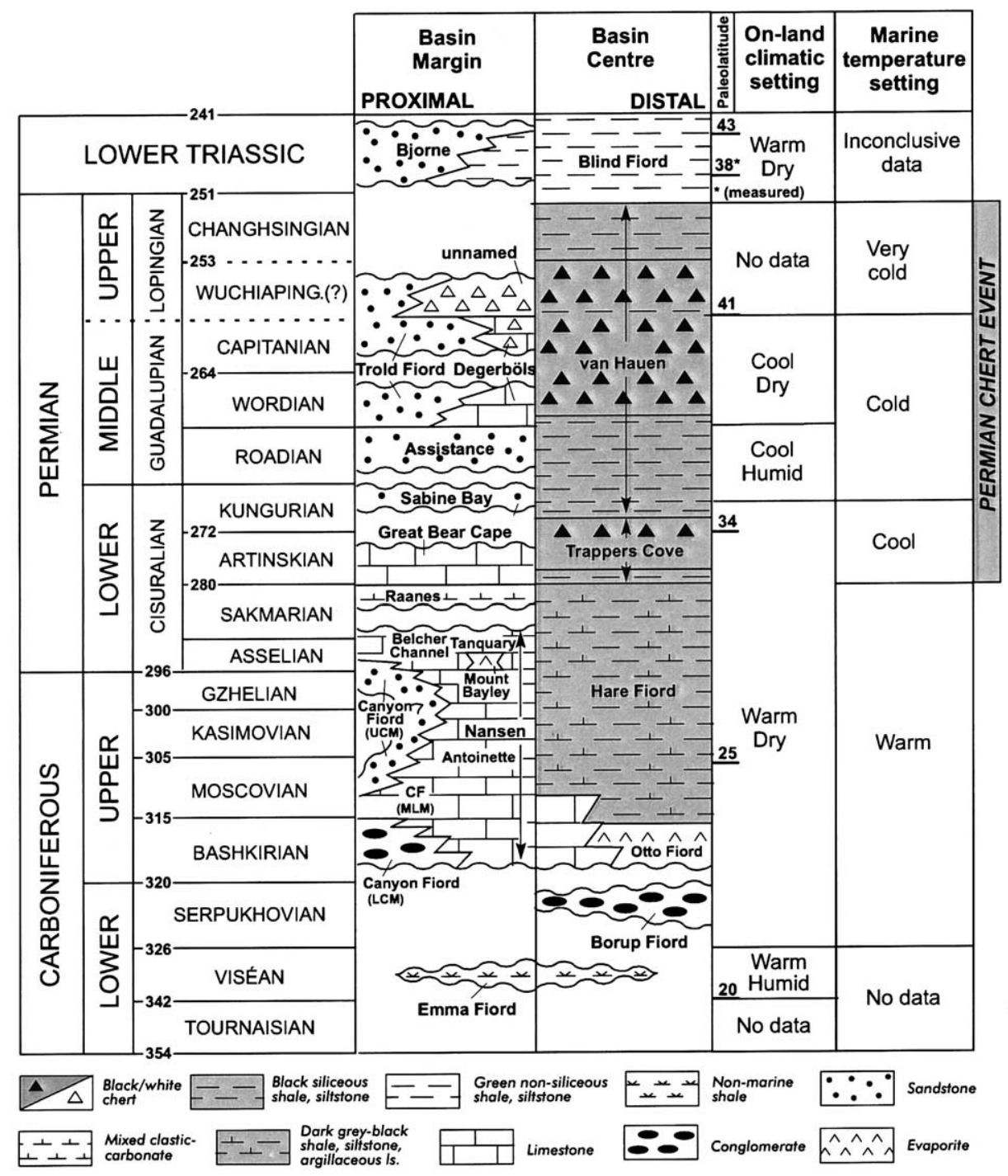

Fig. 1. Stratigraphic chart of Sverdrup Basin showing range of Permian Chert Event against Carboniferous and Permian stages and corresponding radiometric dates (Jin et al., 1997; Menning, 1995), major sequence-bounding unconformities and formations in proximal basin margin areas and correlative units in distal basin centre areas, assumed (Golonka et al., 1994) and measured (Ogg and Steiner, 1991) palaeolatitudes in ${ }^{\circ} \mathrm{N}$, on-land climatic setting based on non-marine indicators (Beauchamp, 1994) and palynomorphs (Utting, 2001), and assumed marine temperatures based on biogenic and abiogenic indicators (Beauchamp and Desrochers, 1997). Modified from Beauchamp (1995) and Beauchamp et al. (2001). 
tions of northern Alaska (Moore et al., 1994; Beauchamp, 1995), the Hart River and Blackie formations of the northern Yukon Territory (Richards et al., 1997; Beauchamp, 1995), the Banff and the Prophet formations from the southwest regions of the Northwest Territories to southwestern Alberta (Richards et al., 1993), the Lodgepole and Middle Canyon formations and the Wilson Creek Member of the Wood River Formation of the northwestern United States (Pole and Sandberg, 1991; Reid and Dorobek, 1991; Mahoney et al., 1991).
The Bashkirian to Sakmarian Hare Fiord Formation of the Sverdrup Basin is a good example of such deposits (Fig. 1). The Hare Fiord Formation comprises spiculitic limestones associated with dark-brown mudrocks (argillaceous limestones, siltstones, shales and cherts) occurring as thinly- to medium-bedded rythmites of turbiditic origin (Fig. 2; see Thorsteinsson, 1974; Davies, 1977; Beauchamp et al., 1995b). The Hare Fiord Formation is the distal, slope to basinal equivalent to the Nansen Formation and equivalent formations (Fig. 1). These more proximal units form
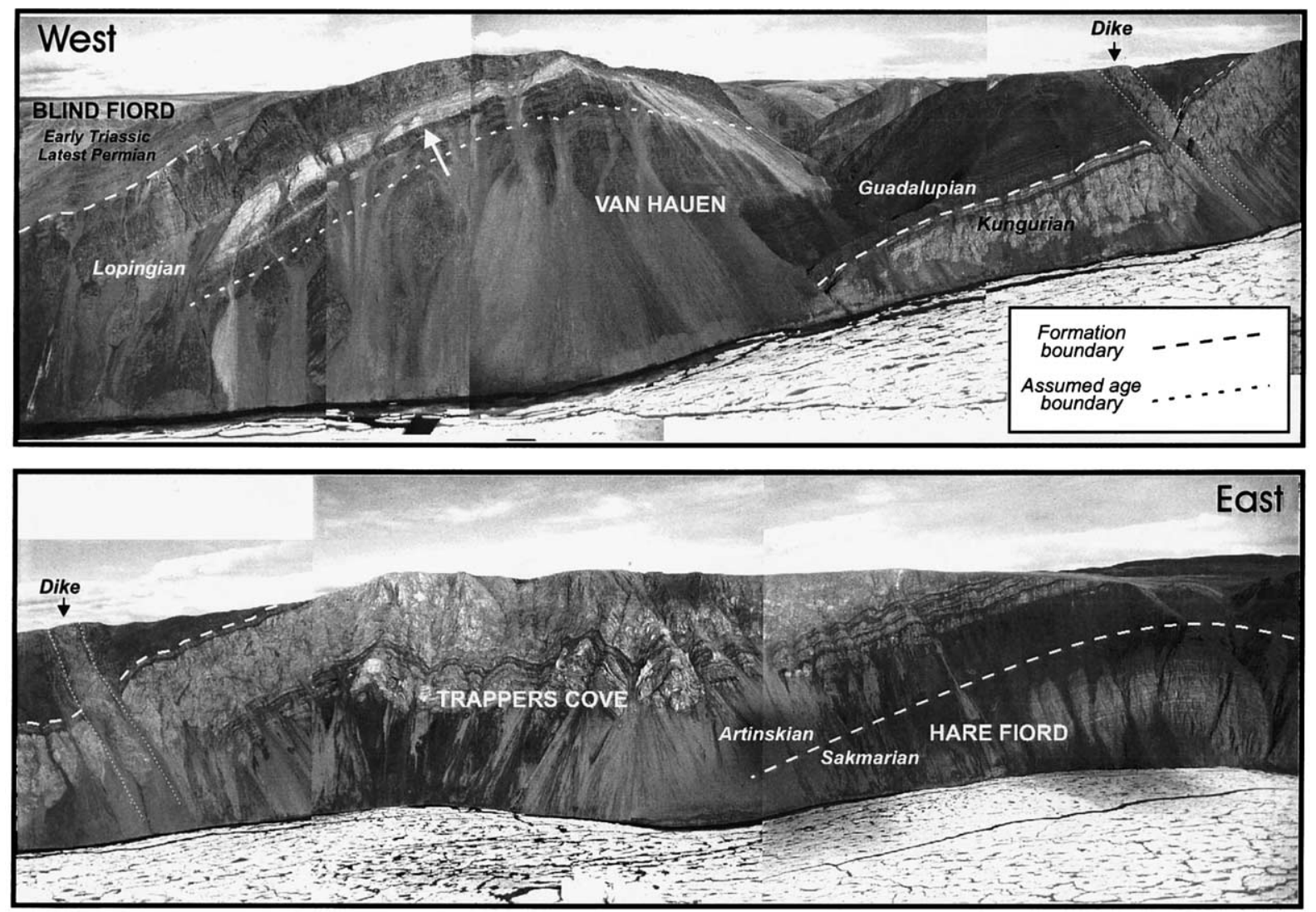

Fig. 2. Permian Chert Event (PCE) west and east of Smith Creek, NW Ellesmere Island. Onset of PCE corresponds to contact between Sakmarian and older Hare Fiord Formation and Artinskian to Kungurian Trappers Cove Formation. Demise of PCE corresponds to contact between Guadalupian and Lopingian van Hauen Formation and latest Permian-Early Triassic Blind Fiord Formation. More than $3 \mathrm{~km}$ of coastline is shown. A Cretaceous dike provides a tie between two sets of composite photographs. Hare Fiord Formation comprises $250 \mathrm{~m}$ of turbiditic slope mudrocks (variably cherty, argillaceous spiculitic limestones). Trappers Cove Formation is $400 \mathrm{~m}$ of basin to slope black siliceous shales passing upward into cliff-forming spiculitic cherts. Van Hauen Formation is composed of $400 \mathrm{~m}$ of siliceous shales passing upward into black spiculitic chert. Light-coloured unit (white arrow) high in the van Hauen Formation is a prograding tongue of relatively shallow spiculitic cherts. Blind Fiord Formation comprises chert-free shales and siltstones. 
a thick succession of reefal shelf-edge and cyclic shelf carbonates that range from deep- and coolwater wackestones and packstones to shallow- and warm-water packstones and grainstones. The latter accumulated under warm tropical-like conditions as shown by high rates of carbonate production associated with a rich and diversified chloroforam
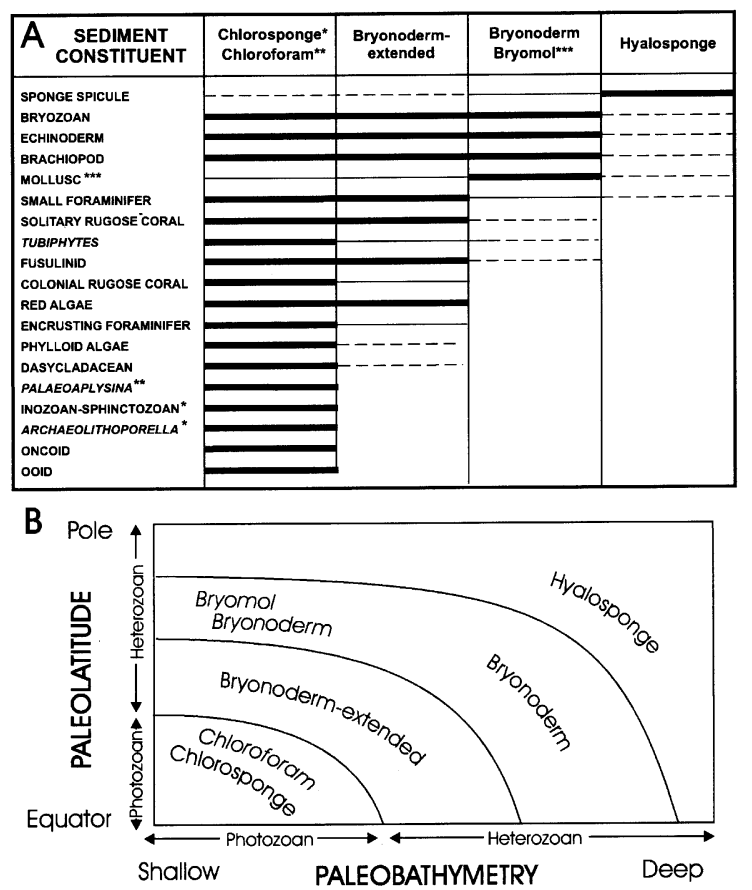

Fig. 3. (A) Biotic composition and associated non-skeletal elements (ooids, oncoids) of warm- (chlorosponge, chloroforam), cool- and cold- (bryonoderm-extended, bryonoderm, bryomol), and very cold-water (hyalosponge) Late Paleozoic biogenic sediments. Inozoan and sphinctozoan sponges and Archaeolithoporella are restricted to chlorosponge assemblage. Palaeoaplysina is part of chloroforam assemblage. Molluscs (bivalves) are abundant only in bryomol assemblage. (B) Hypothetical, mostly temperature-controlled, distribution of warm- to very cold-water assemblages related to water depth and latitude. Modified after Beauchamp (1994) and Beauchamp and Desrochers (1997). Photozoan and heterozoan terminology from James (1997). Photozoan assemblages and associated carbonates formed in warm and shallow environments. Heterozoan assemblages and associated carbonates formed in a variety of shallow- to deep-, cool- to cold-water environments. Other factors such as salinity fluctuations and light deprivation (Lees and Buller, 1972; Lees, 1975) can cause heterozoan sediments to accumulate even in relatively warm water. biota (Fig. 3; Beauchamp, 1994; Beauchamp and Desrochers, 1997). A wide variety of phylloid algal and Palaeoaplysina buildups ranging from small patch reefs to large continuous reef-tracts occur throughout the Bashkirian to Sakmarian succession (Beauchamp et al., 1989a,b,c; Beauchamp, 1993). Marine cements in the form of aragonite botryoids and high-Mg radiaxial crusts are ubiquitous throughout these deposits (Davies and Nassichuk, 1991). Ooids and oncoids are common to abundant.

Early Permian warm-water chloroforam carbonates form a several thousand kilometre long belt (Fig. 4A; Table 1), that extends from the preUralian and Timan-Pechora areas of Russia to the southwestern USA. Among other warm-water organisms (Stevens, 1982; Fedorowski et al., 1999), this belt is characterised by the presence of Palaeoaplysina, the plate-like hydrozoan(?) that occurs in association with phylloid algae within both reefal and non-reefal successions (Beauchamp et al., 1989a; Breuninger et al., 1989; Ritter and Morris, 1997). Palaeoaplysina is not present in the Tethys or in southwestern USA (Fig. 4A) where warm-water carbonates are represented by a more diversified chlorosponge assemblage (Fig. 3; Beauchamp, 1994; Beauchamp and Desrochers, 1997). Palaeoaplysina-bearing chloroforam biota coexists with Tethyan-like chlorosponge biota in the reefal succession of the southern Urals (Vennin, 1997).

\subsection{Onset of PCE: Late Sakmarian-Early Artinskian}

For Murchey and Jones (1992), massive chert deposition in the deep distal environments of northwest Pangea started at some indeterminate time during the Leonardian, that is during either the Artinskian or the Kungurian. Much of this uncertainty reflects the difficulty of equating Permian biostratigraphic schemes, based on radiolarians, with those based on benthic shelly fossils, or conodonts. In addition, the lack of biostratigraphically-reliable Lower Permian deeper-water spicule-rich sections along the margin of western North America prevented Murchey and Jones (1992) from providing a better estimate of the 
onset of the PCE. A far more precise answer comes from the Sverdrup Basin.

Spiculitic chert is the dominant lithology in the Artinskian Trappers Cove Formation which overlies the Sakmarian Hare Fiord Formation in the distal areas (Figs. 1 and 2). Up to $1 \mathrm{~km}$ of thinlyand medium-bedded Trappers Cove cherts interfinger with subordinate shales, siltstones and scattered carbonate tongues of turbiditic origin (Beauchamp and Henderson, 1994). These darkcoloured strata, representing slope to basinal sedimentation, pass upward and cratonward into carbonate deposits of the Great Bear Cape Formation (Fig. 5), a non-cyclic succession of cherty, fine-grained carbonates passing upward into coarser fossiliferous packstones and grainstones. The Great Bear Cape Formation is dominated by sponge spicules, bryozoans, echinoderms and brachiopods (bryonoderm assemblage; see Fig. 3 ). In addition to this biota, the shallowest-water grainstones in the Great Bear Cape Formation locally contain large fusulinaceans and colonial rugose corals (bryonoderm-extended assemblage of Beauchamp and Desrochers, 1997; see Fig. 3). Carbonate buildups are rare in the Great Bear Cape Formation and form isolated mud mounds comprising bryozoan and soft-bodied sponges as the main constituents (Beauchamp, 1989). Submarine cements are non-existent even in the shallowest-water grainstones. Radiaxial high-Mg cal-
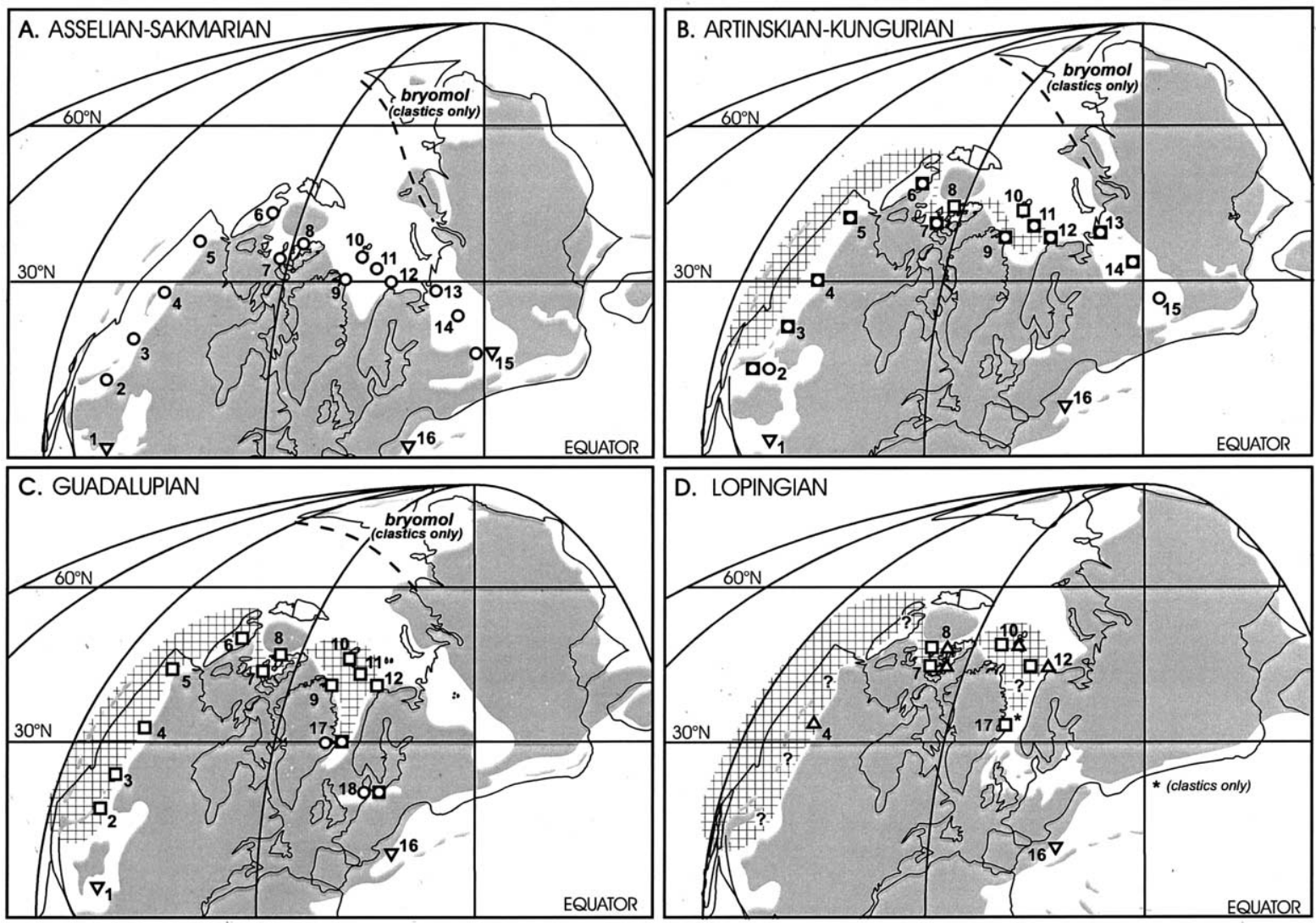

Land

Areas of biogenic chert accumulation

Shallow-water assemblages in carbonates (Asselian to Lopingian) \& cherts (Lopingian only) $\nabla$ Chlorosponge 0 Chloroforam $\square$ Bryonoderm-extended $\square$ Bryonoderm

$\Delta$ Hyalosponge

Fig. 4. Permian palaeogeography of northwest Pangea showing land, sea, areas of biogenic chert deposition and shallow-water benthic assemblages. (A) Asselian-Sakmarian. (B) Artinskian-Kungurian. (C) Guadalupian. (D) Lopingian. Paleogeography by Ziegler et al. (1997), modified to display open seaway between Northern Alaska (rotated) and Sverdrup Basin (Embry, 1993), and to show area of marine deposition between North Greenland and Svalbard. Numbered localities are as in Table 1. 
cite isopachous layers occur in association with bryozoan-dominated facies in the mud mounds (Beauchamp, 1993, 1989).

The Great Bear Cape Formation represents a distally-steepened, cool-water carbonate ramp that prograded laterally into slope to basinal spiculitic cherts of the Trappers Cove Formation (Beauchamp and Henderson, 1994; Beauchamp and Desrochers, 1997). The entire succession is shallowing upward and forms the Artinskian regressive systems tract (RST) of a Sakmarian-Artinskian T-R sequence (Fig. 5), the transgressive systems tract (TST) of which is represented by the Sakmarian Raanes Formation. The maximum flooding surface (MFS) of the sequence marks the onset of the Permian Chert Event. A conodont assemblage comprising Streptognathodus inornatus, Adetognathus paralautus and Mesogondollela bisselli straddles this surface. This assemblage was originally correlated with the upper part of the Aktastinian substage of the Artinskian (Beauchamp and Henderson, 1994). However, fusulinaceans recovered from within the Raanes Formation at Grinnell Peninsula, Devon Island, have indicated a Sakmarian age for an interval that also contains $S$. inornatus and $A$. paralautus (Beauchamp et al., 1998). Accordingly, Henderson and Mei (2000) and Mei and Henderson (2001) now roughly correlate the Raanes-Great Bear Cape contact with the Sakmarian-Artinskian boundary, which is the age interpretation followed herein and corroborated by other fossil groups such as colonial corals, ammonoids, small foraminifers and fusulinaceans (Beauchamp et al., 1998). The onset of the PCE is hence dated at or very near the SakmarianArtinskian boundary (Fig. 5). In addition to the maximum flooding, this event coincides with the ending of high-frequency/high-amplitude shelf cyclicity, the onset of massive biogenic chert deposition in the deep-water distal areas, and a longterm shift from warm- to cool-water carbonate sedimentation in the shallow-water proximal areas (Fig. 1). A coeval shift to cool-water carbonates in the proximal areas and massive chert deposition in the distal areas can be traced from Svalbard and the Barents (Fig. 4B, Table 1) to the
Nevada-Idaho border to the south (Riepetown Formation; Murchey and Jones, 1992).

\subsection{Expansion of PCE: Guadalupian}

More than $1 \mathrm{~km}$ of late Early, Middle and Late Permian cherts belonging to the van Hauen Formation occur in the distal areas of the Sverdrup Basin (Fig. 1). The van Hauen Formation (Thorsteinsson, 1974) is composed of dark-coloured spiculitic cherts (Fig. 2), associated with minor turbiditic limestones, siltstones and shales that accumulated in a distal, slope to basinal setting (Desrochers and Beauchamp, 1995). Age-diagnostic conodonts (Beauchamp et al., 1989b), brachiopods (Thorsteinsson, 1974), palynomophs (Utting, 1994) and one ammonoid (Nassichuk, 1995) have been recovered in the van Hauen Formation and equivalent units. The van Hauen Formation is a continuous sedimentary unit that records distal deposition of three broad sequences that are bounded by major unconformities in the proximal areas (Fig. 1; Beauchamp et al., 1989b,c; Beauchamp and Thériault, 1994; Beauchamp, 1995). The middle sequence of RoadianWordian age shallows up and passes landward into the correlative Degerböls Formation, which is composed of cherty limestones dominated by sponge spicules, bryozoans, brachiopods and echinoderms (bryonoderm assemblage; see Fig. 3), associated with minor solitary rugose corals ( $\mathrm{Cal}$ ophyllum fauna of Fedorowski and Bamber, 2001), frondicularid foraminifers and rare molluscs. The formation is devoid of fusulinaceans, colonial corals, calcareous algae or reefs. There is no submarine cement even in the shallowest water facies represented by cross-bedded, high-energy crinoidal grainstones. In contrast, glauconite is an important constituent and is the dominant mineralogical species in the nearshore equivalent Trold Fiord sandstones (Fig. 1), which also locally contain some dropstones (Beauchamp, 1994). The impoverished biotic composition of the Degerböls carbonates, the lack of marine cement, and the presence of dropstones (floating ice) and of glauconite (slow sedimentation rate) indicate that the Sverdrup Basin area was bathed by 


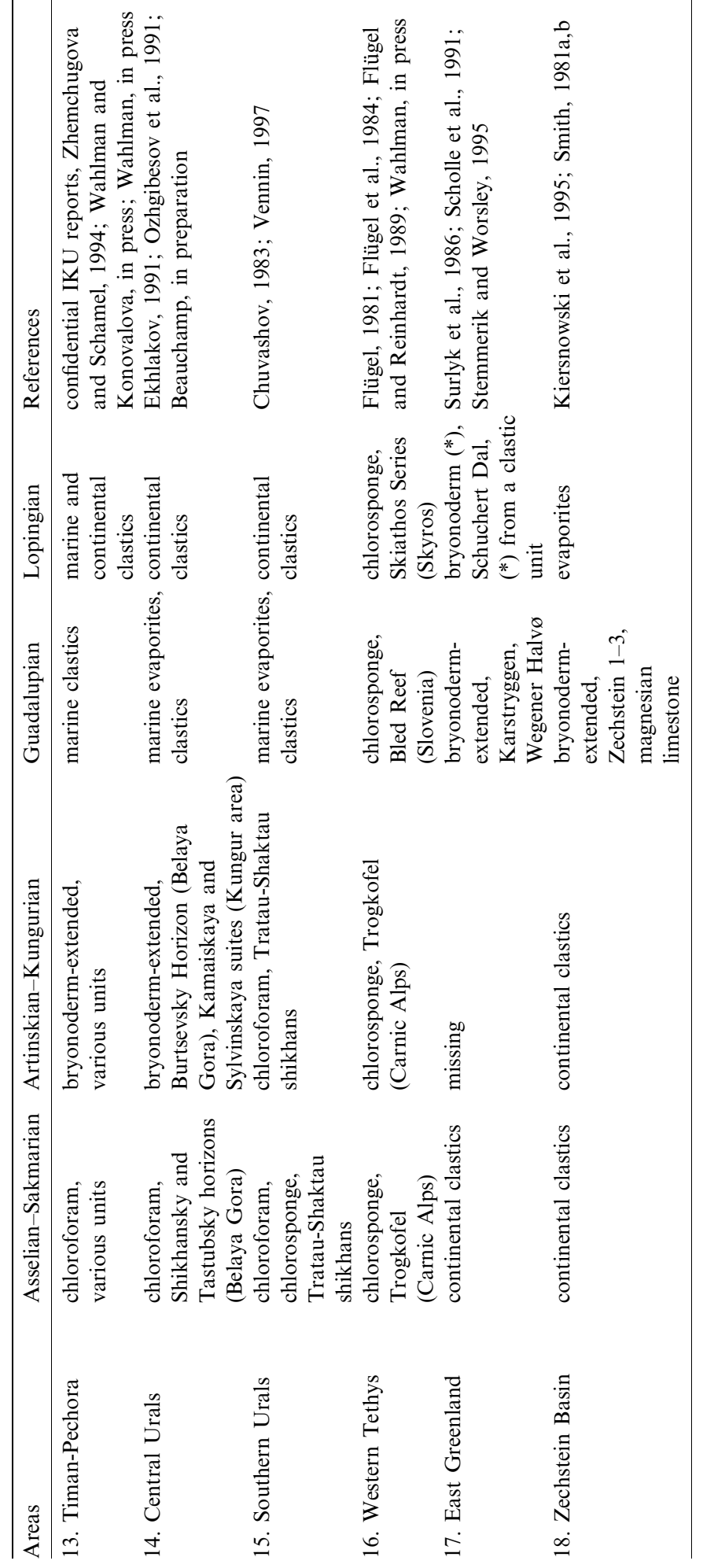


chert-bearing Fantasque Formation of western Canada (Henderson et al., 1993), and Kapp Starostin Formation of Svalbard (Stemmerik and Worsley, 1989) and equivalent units in the Barents Sea (Stemmerik and Worsley, 1995).

There is no Guadalupian warm-water chloroforam-type carbonate along the western margin of North America. Yet chlorosponge warm-water carbonates are ubiquitous in West Texas (Fig. 4C). Guadalupian warm-water carbonates also accumulated in East Greenland where they are represented by a variety of karstified stromatolitic and oolitic facies that belong to the Karstryggen and Wegener Halvø formations (Surlyk et al., 1986). Carbonate buildups that formed in a more offshore setting in the Wegener Halvø Formation comprise a typical bryonoderm biota which probably indicates a deeper-water, not necessarily colder, environment. However, the Ravnefjeld Formation, a deeper-water mudrock unit laterally equivalent to the Wegener Halvø buildups, contains abundant spiculitic cherts (Surlyk et al., 1986).

\subsection{Zenith of PCE: Lopingian}

The Lopingian record of northwest Pangea is poorly understood due to the lack of diagnostic fossils and patchy preservation beneath the subTriassic unconformity. Yet, the Lopingian, at least its early part, is believed to coincide with the zenith of the PCE, as shown by chert-rich strata worldwide. In the Sverdrup Basin, a widespread transgression occurred during the Capitanian leading to the deposition of bryonoderm carbonates and spiculitic cherts in the upper part of the Degerböls and Trold Fiord formations and dark-coloured spiculite in the correlative van Hauen Formation (Fig. 1). A major regression followed, the onset of which is roughly correlated with the Guadalupian-Lopingian boundary (Fig. 6). Distal deep-water cherts are represented by dark-coloured spiculites in the upper part of the unit currently mapped as van Hauen Formation (Fig. 2). These sediments pass upward and landward into pale grey to white spiculitic chert, the more proximal and shallower accumulations of which are either extensively bioturbated or cross-bedded and contain variable amounts of glauconite (Beauchamp et al., 1995a; Beauchamp and Desrochers, 1997). Spiculitic chert (hyalosponge assemblage; see Fig. 3) is the dominant lithology in the distal to proximal Lopingian RST. Rare bryonoderm carbonates occur as pods and lenses. This shallower-water chert is part of a yet unnamed formation containing long-ranging conodonts (Mei and Henderson, 2001). Sedimentary environments represented by the assumed Lopingian chert in the Sverdrup Basin range from distal, deep-water basin and slope to relatively shallow, gently dipping ramp. Sedimentation rates were low as shown by the abundance of glauconite near the basin margin.

As in the Sverdrup Basin, the Late Permian of the Svalbard-Barents Sea area has traditionally been interpreted as missing beneath a widespread sub-Triassic unconformity (see Stemmerik and Worsley, 1989). However, physical and geochemical evidence of Lopingian sedimentation and continuous deposition across the Permian-Triassic boundary has been documented in Svalbard (Gruszczynski et al., 1989; Wignall et al., 1998). The Kapp Starostin Formation is now seen as passing conformably into the overlying Triassic Vardebukta Formation in the more distal areas (Bugge et al., 1995). Likewise, an unnamed palecoloured chert unit encountered in the subsurface of the Finnmark platform (Bugge et al., 1995; Ehrenberg et al., 2000) is identical, stratigraphically and compositionally, to the yet unnamed pale-coloured Late Permian chert unit in the Sverdrup Basin (Fig. 4D). The same applies for western Canada where the upper part of the Fantasque chert could range into the Lopingian (Table 1, Henderson and Mei, 2000) and may be overlain conformably by Early Triassic mudrocks of the Spray River Group (Wang et al., 1994). Lopingian strata are missing beneath the Early Triassic Dinwoody Formation in the Phosphoria Basin of the western USA (Wardlaw et al., 1995), but Lopingian cherts most occur widely in the upper part of the various allochtonous and exotic units from Alaska to California (Cordey, 1998; Cordey et al., 1999).

The only well-dated Lopingian unit along the northwest margin of Pangea is the Schuchert Dal 


\subsection{Demise of PCE: latest Permian}

Biogenic silica factories collapsed during Late Permian time throughout the world. In the Sverdrup Basin, the end of the PCE coincides with the contact between the chert-rich van Hauen Formation (or equivalent proximal chert unit) and the chert-free Blind Fiord Formation (Figs. 1 and 2). Contrary to a long-established belief (Nassichuk et al., 1973; Thorsteinsson, 1974), there is no physical unconformity between these two units in the central and distal parts of the basin, where non-siliceous greenish grey shales of the Blind Fiord Formation lie conformably upon black siliceous shales of the van Hauen Formation. Evidence of erosional truncation does occur in the more proximal areas as the Blind Fiord Formation lies upon progressively older Permian units towards the basin margin. The base of the Blind Fiord Formation in marginal areas recorded the culmination of a major transgression that led to the drowning of previously submerged, shallow- to deep-water basin axial areas and to the flooding of previously emerged areas well beyond the former basin margin. An equally significant and correlative transgression occurred throughout western and northwestern Pangea and units compositionally similar to the Blind Fiord Formation occur from Idaho to the Barents Sea (Baars, 1988; Mørk et al., 1989; Gibson, 1993).

For many years the base of the Blind Fiord Formation was viewed as marking the base of the Triassic period. Four stages (Griesbachian, Dienerian, Smithian, Spathian) defined in the Sverdrup Basin were, until recently, recognised as the standards for Early Triassic time (Tozer, 1967). However, the base of the Blind Fiord Formation, and hence its conformable contact with the van Hauen Formation in the distal parts of the Sverdrup Basin, is now interpreted as lying within the latest Permian Changhsingian stage. This is based on the occurrence of Hindeodus parvus recovered $32 \mathrm{~m}$ above the base of the Blind Fiord Formation in a section south of the head of Otto Fiord, NW Ellesmere Island (Henderson and Baud, 1997). The conodont $H$. parvus has been accepted by the International Commission on
Stratigraphy as the marker for the Permian-Triassic boundary with a stratotype at Meishan, China (Yin et al., 2001). At Otto Fiord South, this key conodont taxa lies above a typical, uppermost Permian association with Neogondolella sp. cf. subcarinata and Neogondolella sp. aff. changxinensis from within the lower part of the Blind Fiord Formation, which also contains the ammonoid Otoceras concavum (Henderson and Baud, 1997). As a result, the demise of the silica factories, not only in the Sverdrup Basin, but around the world is referred to as an 'end-Permian' event or a 'latest Permian' event, as opposed to a 'P-T boundary' event (Fig. 6). The same applies to a number of other biological, geochemical and environmental events that accompanied the transition from the Palaeozoic to the Mesozoic (Baud, 2001). These events invariably occurred prior to the first appearance of $H$. parvus (Bowring et al., 1998; Kozur, 1998a,b).

In the most distal parts of the Sverdrup Basin, the end of the PCE is recorded in the sharp, yet conformable, contact between black shale of the van Hauen Formation and greenish grey shale of the Blind Fiord Formation (Fig. 1). The upper $100 \mathrm{~m}$ of the van Hauen Formation is deepening upward and transgressive. It comprises mediumbedded black spiculitic chert passing upward into increasingly argillaceous and thinly-bedded siliceous shale. The Blind Fiord Formation is broadly shallowing upward and regressive. It comprises very thin, finely-laminated shale, passing upward into increasingly shallow turbiditic siltstone and fine-grained sandstone. The contact between the two formations hence roughly coincides with an MFS.

The end of the PCE is recorded in a possibly less condensed transitional unit between the Blind Fiord Formation and underlying, unnamed spiculitic chert unit south and north of the head of Otto Fiord, NW Ellesmere Island, which lies in a more proximal area of the Sverdrup Basin (Fig. 6). The transitional unit comprises 4-6 m of finely-laminated, pyrite-rich siltstone interfingering with carbonate. The latter, composed of ankerite, occurs as lenses or continuous beds 1$2 \mathrm{~cm}$ in thickness. In thin sections, the carbonates are micritic and display the ghost of scattered to 
abundant dissolved sponge spicules. Pyrite is abundant and occurs as framboids lying along fine laminations in the sediment. Microcrystalline silica is a very minor component as it locally fills the void left by dissolved spicules. The exquisite preservation of the laminations indicates that the sediment was undisturbed by bioturbation. It is believed to represent a rare record of the final phase of the transgression that preceded deposition of the Blind Fiord shale. More importantly it recorded the transition between a chert-rich to a chert-free Sverdrup Basin.

\subsection{Early Triassic Chert Gap: Griesbachian to Spathian}

Spiculitic chert deposition did not resume in the various sedimentary basins and continental slopes along the northwest margin of Pangea where the Mesozoic succession is dominated by clastic sediments. In the Sverdrup Basin, Early Triassic clastic sediments are contained in the Blind Fiord Formation (Figs. 1 and 6), which comprises shales, siltstones and fine-grained sandstones, representing distal sedimentation within an array of environments that ranged from basin, slope to deep clastic shelf (Embry, 1991). Blind Fiord shales comprise only scant fossils (molluscs, bryozoans, ammonoids), the assemblage of which represents post-extinction biota. Red calcareous algae have been reported from the Vardebukta Formation of western Spitsbergen (Wignall et al., 1998; Nakrem and Mørk, 1991), which is correlative and compositionally similar to the Blind Fiord Formation (Mørk et al., 1989). In the Sverdrup Basin, the entire Mesozoic was a time of high clastic influx and carbonates are exceedingly rare throughout the succession, while bedded cherts, cherty mudrocks or even chert nodules are absent.

The Blind Fiord Formation passes cratonward into the Bjorne Formation (Fig. 1), which comprises sandstones associated with minor shales and conglomerates that were deposited in a variety of environments ranging from shallow shelf, nearshore subtidal, shoreface to non-marine (Embry, 1991). Fluvial overbanks in the Bjorne Formation are invariably red-coloured and associated with caliche palaeosols, which does indicate a return to a more arid, and presumably warmer, setting during the Early Triassic, a suggestion corroborated by the palynological record (Utting, 1994, 2001).

There is no Griesbachian and Dienerian chert in the rock record. In Japan, where the oldest record of Triassic chert is preserved in a deep oceanic setting (Isozaki, 1994), deposition of siliceous claystone resumed during the Smithian, but bona fide radiolarian and spiculitic chert reoccurred only during the Late Spathian (late Early Triassic) or the Anisian (early Middle Triassic), that is after a 8-10 Ma interruption (Isozaki, 1997; Kakuwa, 1996; Suzuki et al., 1998). The gap appears the same in the Cache Creek Terrane of British Columbia (Isozaki, 1997; Cordey, 1998). Radiolarian chert deposition resumed only during the Late Triassic in the deep oceanic record of Alaska (Murchey et al., 1988).

\section{Discussion and implications}

\subsection{Formation and preservation of biogenic chert}

Six fundamental conditions have to be met for biogenic siliceous sediments to precipitate, accumulate and be preserved as bedded chert in the rock record. These are: (1) an adequate supply of silica and nutrients into the world oceans (Laschet, 1984; Racki, 1999), (2) a mechanism for bringing silica and nutrients to the site of biogenic productivity and maintaining a steady supply thereof (Wilde et al., 1990; McGowran, 1989), (3) an opportunistic pelagic and/or benthic silica-secreting biota capable of taking advantage of an adequate supply of silica and nutrients (Hein and Parrish, 1987; Racki, 1999), (4) a suitable marine environment for this biota to flourish (Hein and Parrish, 1987; Racki, 1999), (5) a favourable post-mortem setting in the water column, on the sea-floor and in the shallow burial environment to minimise silica dissolution (Laschet, 1984; Nelson et al., 1995), and (6) minimal dilution with carbonate and/or clastic sediments to ensure purity of the chert facies (Laschet, 1984). Conditions 1-4 dictate the extent of silica 
precipitation. Condition 5 controls the degree to which biogenic silica will withstand dissolution and accumulate as sediments. Condition 6 determines whether pure chert or a mixture of various lithologies will enter the burial environment. Major fluctuations in anyone of these conditions over geological times could have led to either chert-rich or chert-poor intervals (Hein and Parrish, 1987).

Modern oceans are undersaturated with respect to silica due to biological activity. Because opaline silica is unstable (Laschet, 1984), at least $50 \%$ of the silica produced by diatoms in the euphotic zone dissolve in the upper $100 \mathrm{~m}$ of the water column (Nelson et al., 1995). Chemical and physical weathering of the continents provides the main source of dissolved and particulate silica, which is transported as river runoff $(83.5 \%)$ and aeolian dust (7.5\%) (Treguer et al., 1995). Only a minor portion of marine silica $(3.0 \%)$ comes from the Earth's interior through submarine venting and other hydrothermal processes associated with volcanic centres, whereas twice as much $(6.0 \%)$ silica is derived from the submarine weathering of sea-floor basalts (Treguer et al., 1995; Harrison, 2000). According to Racki (1999), secular episodes of unusually high chert deposition are likely to represent times of increased supply of silica in the world oceanic system, due to increased weathering and/or volcanism. Similarly, Gammon et al. (2000) invoked a local riverine influx of nutrients to explain the presence of Eocene spiculitic cherts in southern Australia. A simple application of these ideas would be that the PCE was a time of increased input of silica and/or nutrients into the world oceans, whereas the ETCG coincides with a time of reduced input. This hypothesis finds little support in the geological record.

There is no reason to suggest that increased volcanism triggered the onset of the PCE during the Late Sakmarian-Early Artinskian interval, nor that the Early Triassic was a time of reduced volcanism. The ${ }^{87} \mathrm{Sr} /{ }^{86} \mathrm{Sr}$ curve of marine sediments does show a significant late Early to Middle Permian trend towards radiogenic values (Denison and Koepnick, 1995; Martin and Macdougall, 1995), which may suggest an increase in volcanic input, but may equally indicate a de- crease in continental contribution. However, this trend sharply reverses near the Middle/Late Permian boundary at a time when chert deposition appears to have increased worldwide. Likewise, the end-Permian massive eruption of the Siberian traps (Campbell et al., 1992; Renne et al., 1995) coincides with the collapse, not the outburst, of chert factories around the world.

There is also no reason to believe that continental weathering increased dramatically across the Sakmarian-Artinskian boundary and triggered the onset of the PCE. Episodic waxing and waning of Gondwana glaciers until the Sakmarian (Dickins, 1996) must have led to significant continental weathering and a steady flux of silica and nutrients to the oceans before the PCE (Froelich et al., 1992; Harrison, 2000). Likewise, the Late Carboniferous and Permian weathering of the Hercynian-Alleghanian and Ural mountains must have provided a steady supply of dissolved silica and nutrients to the oceans (Ruddiman and Prell, 1997), both before and after the onset of the PCE. The presumed increase in atmospheric $\mathrm{CO}_{2}$ often invoked as a cause for the end of Gondwana glaciations (Berner, 1990, 1991; Frakes et al., 1992) would have led to increase continental weathering. In contrast, the demise of Gondwana glaciers coupled with the final consolidation of Pangea would have led to reduced continental weathering as increasingly arid areas were created (Herring, 1995; Barron and Fawcett, 1995; Francis, 1994; Crowley, 1994) and a megamoonsonal climate was established (Parrish, 1993). Thus, it is not clear to what extent the PCE corresponded with an increase in weathering and flux of continental silica and nutrients to the oceans. As discussed before, silica-secreting organisms (radiolarians, sponges) flourished both before and after the onset of the PCE. What the PCE truly brought was a major increase in the preservation of bedded chert, which may or may not have been associated with a significant increase in productivity.

\subsection{Permian cooling}

The onset of the PCE in the deeper-water distal areas coincides with a shift from highly diversi- 
fied, warm-water carbonates to faunally-impoverished cool- and cold-water carbonates in the shallow proximal areas. This shift is a clear indication that much colder marine conditions were established at about the Sakmarian-Artinskian boundary along the northwest margin of Pangea. To some extent, this cooling can be associated with the northward migration of Pangea during the Late Palaeozoic. Various reconstructions (Golonka et al., 1994; Scotese and Langford, 1995; Ziegler et al., 1998; Golonka and Ford, 2000) show that the Sverdrup Basin migrated from about $25^{\circ} \mathrm{N}$ during the Late Carboniferous to about $40^{\circ} \mathrm{N}$ during the Early Triassic (Fig. 1). Palaeomagnetic measurements performed on the Blind Fiord Formation have indicated a palaeolatitude of about $38^{\circ} \mathrm{N}$ during the Early Triassic (Ogg and Steiner, 1991). Non-marine climatic indicators support the inference that the Sverdrup Basin traveled from a semi-arid subtropical zone to a more humid, subtemperate zone during the Kungurian (Ziegler et al., 1997). Accordingly, lower Kungurian and older fluvial overbank deposits are invariably red and associated with nodular to massive caliches, whereas their upper Kungurian and Roadian depositional counterparts are black, coaly shales without pedogenic nodules (Thériault and Desrochers, 1994; Beauchamp, 1994; Beauchamp et al., 2001). Likewise, evaporite deposits and pseudomorphs after halite and gypsum occur throughout the Artinskian and older succession, but are absent in the upper Kungurian and younger Permian succession. The composition of palynoflora also suggests a shift to a more humid climatic setting across the Artinskian-Kungurian boundary (Utting, 1994; Beauchamp et al., 2001), and a return to dryer conditions during the Wordian and possibly Capitanian (Utting, 2001).

The disappearance of warm-water carbonates at about the Sakmarian-Artinskian boundary seems to predate, by as much as 5-10 million $\mathrm{yr}$, the passage from subtropical to subtemperate latitudes (Fig. 1). More puzzling is the establishment of apparently much colder marine conditions during the Guadalupian and yet again during the Lopingian, at a time when the Sverdrup Basin probably lay at about $35^{\circ} \mathrm{N}$. These condi- tions prevailed all along the northwest margin of Pangea, as far south as northern Nevada, which lay at a palaeolatitude not exceeding $15^{\circ} \mathrm{N}$. Clearly there appears to be a discrepancy between the non-marine and the marine Permian record of northwest Pangea. While the former supports the palaeolatitudinal interpretation, at least up until the Kungurian, the latter suggests that the area was under the influence of cold to very cold waters. These findings therefore suggest that it is an influx of cold, northerly-derived waters along the margins of northwest Pangea, independent of on-land climates, that led to the onset, expansion and zenith of the PCE.

\subsection{Thermohaline circulation}

Oceanic upwelling has been invoked to explain the presence of shallow- and cool-water carbonate facies along the western margin of North America. For instance, upwelling accompanied by a landward surge of the thermocline was the explanation provided by Brandley and Krause (1994, 1997) to account for the formation of ikaite concretions and relatively shallow- and cool-water carbonates offshore of warm-water carbonates in the Viséan succession of western Canada. Likewise, cold oceanic upwelling was the explanation offered by Murchey and Jones (1992) for the origin of the PCE and its association with phosphate-rich deposits along western North America. Accordingly, eastward-directed upwelling, resulting from Coriolis-driven wind-forcing along the western continental margin of Pangea, is a plausible explanation, since the area was in the northern hemisphere from the Early Carboniferous onward (Scotese and Langford, 1995). A northern gyre would have also generated a southbound surficial current akin to the modern California Current and would have brought cold waters all along northwest Pangea (Fig. 7A). However, since background upwelling and surficial circulation remained more or less the same throughout the Carboniferous, Permian and Triassic periods (Golonka et al., 1994), the introduction of much colder waters from the Artinskian onward calls for an additional northern source.

It is the thermohaline circulation of northerly- 

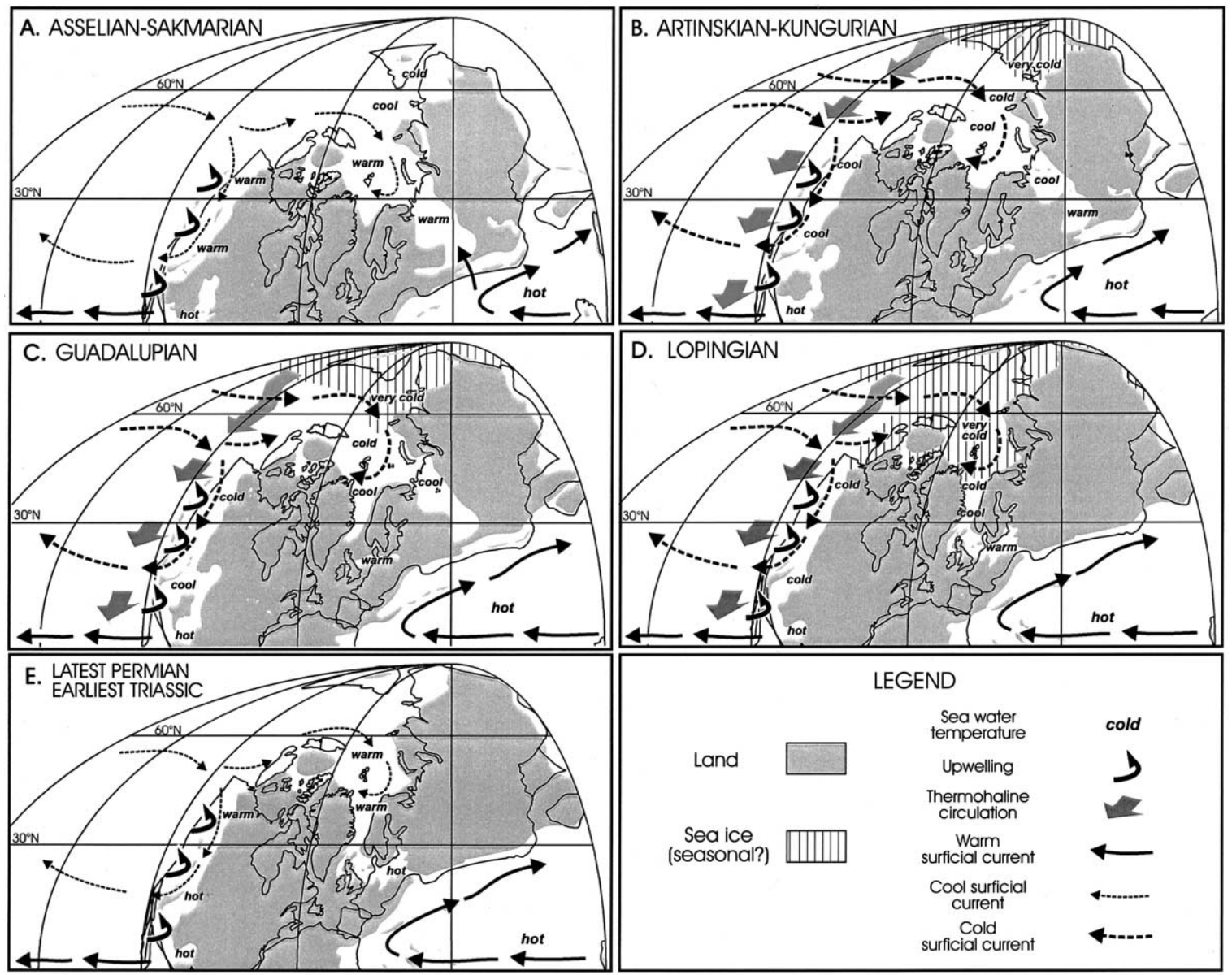

Fig. 7. Palaeogeographic maps of northwest Pangea showing land, sea, extent of assumed sea ice, patterns of surficial warm, cool and cold circulation, upwelling, thermohaline circulation, and interpreted seawater temperatures. Paleogeography modified after Ziegler et al. (1997) to display open seaway between Northern Alaska (rotated) and Sverdrup Basin (Embry, 1993), and to show area of marine deposition between northern Greenland and Svalbard. (A) Asselian-Sakmarian. (B) Artinskian-Kungurian. (C) Guadalupian. (D) Lopingian. (E) Latest Permian-earliest Triassic.

derived nutrient-rich, cold marine waters along the northwestern and western margin of Pangea, in concert with the regional low clastic influx, that likely provided the conditions necessary for the onset, expansion and zenith of the PCE. Given that a sufficient flux of dissolved silica and nutrients from continental weathering and other sources entered the Carboniferous and Permian oceans somewhere (adequate supply), and that healthy populations of silica-secreting radiolarians and sponges already existed (adequate bio$t a$ ), the introduction of cold waters and its circulation and upwelling along the western and northwestern margin of Pangea provided a mechanism that replenished the supply of silica in the area (efficient transportation), created a nutrientand oxygen-rich environment favouring siliceous biogenic productivity (suitable environment), established cold sea-floor conditions hindering silica dissolution while increasing calcium carbonate solubility (favourable post-mortem setting), and provided conditions stressful to biogenic and abiogenic carbonate production (minimal sediment dilution), which emptied benthic niches and made them available for colonisation by siliceous sponges. 


\subsection{Northern sea ice}

Invoking thermohaline circulation as a major contributing factor to the PCE leads to a more fundamental question: what was the engine of that circulation and what caused this engine to be set in motion near the Sakmarian-Artinskian boundary, to function increasingly well for the next $30 \mathrm{Ma}$ and to stop abruptly near the end of the Permian?

In the modern oceans, thermohaline circulation in the deep sea is generated by the formation of cold, dense water in the polar regions that then sinks and flows toward the equator, displacing a number of water masses and generating upward movements of nutrient-rich waters (Pinet, 1992). For instance, the North Atlantic deep-water current (NADW), which originates between Greenland and Svalbard as cold melt water from the seasonal thawing of the Arctic ice sheet, sinks and travels from the North to the South Atlantic. Cold and less saline waters originating from the seasonal thawing of Arctic sea ice also flows southward in shallower depths along the eastern Greenland Shelf (East Greenland Current), northward along western Greenland (West Greenland Current) and southward again along the Labrador Shelf (Labrador Current). This influx of Arctic waters causes sea water temperatures to remain low throughout the year and seasonal sea ice to form as far south as Nova Scotia in areas beyond the reach of the Gulf Stream. Blankets of siliceous sponge spicules, in many ways similar to the Lopingian spiculitic deposits of northwest Pangea, currently accumulate in relatively shallow water on the Vesterisbanken Seamount, in the central Greenland Sea (Henrich et al., 1992), an area under sea ice cover half of the year. Spiculitic blankets are also known to form beneath, or near the edge of, permanent sea ice both in the Arctic and Antarctic, where the absence of light, in addition to very cold water temperatures stress most carbonate producers (Bullivant and Dearborn, 1967; Domack, 1988; Van Wagoner et al., 1989).

We suggest that the northwest margin of Pangea was, for nearly 30 Ma during the Permian, bathed by cold waters derived from the seasonal melting of northern sea ice (Fig. 7B). As with the NADW, melt water would have sunk into the deep north Panthalassa Ocean displacing nutrients- (including phosphorus, nitrogen and iron) and silica-rich waters in its path (Wilde et al., 1990), much of it would have been forced along the margin of northwest Pangea via upwelling. Likewise, some of the lighter, perhaps hyposaline, seasonal melt must have been captured by the clockwise wind-driven northern gyre and would have flowed all along northwest Pangea. This process started near the Sakmarian-Artinskian boundary, intensified throughout the Middle and Late Permian time and ceased suddenly in latest Permian time. It led to oceanic conditions much colder than normally expected from the palaeolatitude of the area (Figs. 7B-D), and hence to a substantial increase in the pole-to-equator temperature gradient. Accordingly, the influence of cold northerly-derived water was felt as far south southern Nevada. If the presence of shallow-water spiculitic blankets and the scarcity of carbonate elements are any indication of an at least seasonal ice cover as in modern environments, then sea ice, at least seasonal in nature, must have existed in the Barents Sea and in the Sverdrup Basin during the Lopingian (Fig. 7D). Accordingly, Ustritsky (1973) and Epshteyn (1981) documented several horizons of dropstones in the Middle Permian of the Kolyma Block in Siberia, suggesting that ice existed at high latitudes. Occurrences of Middle Permian dropstones were also documented in the Sverdrup Basin (Beauchamp, 1994). Noteworthy, cooling and polar ice buildup were also invoked by McGowran (1989) to explain the 'Eocene Silica Burb'.

The idea that northern sea ice built up from the Artinskian onward challenges some of the most established ideas about global Permian climatic evolution. The widespread occurrence of Late Carboniferous and Early Permian glacial deposits in Gondwana and their replacement by coal measures during the Middle and Late Permian has traditionally been seen as indicative of significant global warming (Visser, 1995; Dickins, 1993, 1996). For many, this observation vindicates a popular $\mathrm{CO}_{2}$ balance model (Berner, 1990, 1991), whereby Late Permian atmospheric $\mathrm{CO}_{2}$ 
levels would have been several times their Early Permian and Late Carboniferous levels, hence resulting in a much warmer Middle and Late Permian world. Based strictly on the distribution of land plants, Rees et al. (1999) modeled an ice-free Wordian Pangea, with warm temperate conditions occurring at high northern latitudes from Taymir Peninsula to northern Alaska (see also Ziegler et al., 1998). However, the idea of high atmospheric $\mathrm{CO}_{2}$ levels during the Late Permian has been challenged by Ekart et al. (1999) who suggested instead that Permian $\mathrm{CO}_{2}$ levels were generally low, with a rather sharp decrease during the Late Permian. It is difficult to envision the growth of northern sea ice and the Middle to Late Permian contraction of warm-water carbonate factories around the palaeoequator as indicative of a world that was getting warmer. Likewise, the recent documentation of permafrost features in some of the Late Permian coal measures of Australia (Retallack, 1999) surely indicates that much of Gondwana was still under a cold climatic setting despite the lack of glacial deposits. The occurrence of Cordaites plants (Rees et al., 1999) on lands in proximity to marine sea ice in the northern hemisphere could be indicative of extreme seasonality expected for the Pangean configuration (Parrish, 1993), a unique setting with no modern counterpart.

The buildup of northern sea ice, however, may not be indicative of global cooling (Stanley, 1988) but rather of a set of palaeoceanographic conditions that favoured sea ice formation in the northern hemisphere. The progressive impingement of the northernmost tip of Pangea upon the polar regions from the Artinskian onward could have favoured the creation and deflection of cold-water masses along continental margins (Stanley, 1984, 1988), and promoted the growth of sea ice. The closure of the Uralian trough by Kungurian time must have led to further cooling of the area as warm southerly-derived water was suddenly prevented from entering the northern areas (Stemmerik, 1997). It is possible, and even likely, that the demise of Gondwana glaciers and the following buildup of northern sea ice led to a reversal of thermohaline circulation on a global scale. Without knowing the ultimate cause, we suggest that the temporal coincidence of a global maximum flooding event, termination of cyclothemic sedimentation, demise of Gondwana ice sheets, formation of northern sea ice, influx of cool northern oceanic waters along northwest Pangea, and the onset of the PCE constitutes a chain of events that reflects a profound and irreversible palaeoceanographic shift at the Sakmarian-Artinskian boundary (Fig. 7A, B).

\subsection{End-Permian global warming}

Evidence is mounting that the end-Permian environmental turnover was accompanied by significantly warmer climatic conditions throughout the world. Based on his study of palaeosols in Australia and other areas of Gondwana, Retallack (1999) argued for a major greenhouse warming that accompanied, and perhaps followed, a massive turnover in the land plant populations of the southern hemisphere. He believes that the climate shifted from relatively cold and humid during the Late Permian as expected from the high palaeolatitudes of the areas he studied, to much warmer and dryer during the Early Triassic unexpected for the palaeolatitudes of the area. In that vein, proponents of the idea that a major anoxic event was associated with the end-Permian extinction have more than once suggested that it is a warmer global environment that led to sluggish circulation and fostered anoxia (Wignall and Hallam, 1992). The brief return to a carbonate mud-forming environment in the transitional unit at the base of the Blind Fiord Formation and the presence of redbeds and caliche-bearing fluvial overbank strata in the correlative Bjorne Formation may also provide some evidence for a warmer climatic setting (Fig. 1).

The end-Permian global warming provides a simple explanation for the collapse of chert factories along northwest Pangea. Indeed, warming would have led to a net reduction, and perhaps complete thawing, of northern sea ice hence eliminating the engine of thermohaline circulation (Fig. 7E). This would have led to the breakdown of the conditions favourable to the production, accumulation and preservation of biogenic chert. A much warmer marine environment accompa- 
nied by sluggish circulation of oxygen-, silica- and nutrients-poor waters would have applied significant stress upon biogenic productivity, while increasing the solubility of biogenic silica in the water, on the sea-floor and in the shallow burial environment. Likewise, warmer conditions would have favoured the inorganic production of carbonate mud diluting any biogenic silica that may have been produced. The sluggish circulation would also have favoured pervasive oceanic stratification and life-stressing sea-floor anoxia (Wignall and Hallam, 1992; Wignall and Twitchett, 1996; Wignall et al., 1998).

The end of the PCE and the ensuing ETCG do not, however, correspond to a simple return to pre-PCE conditions. The absence of Early Triassic chert worldwide attests for a Mesozoic world that is much different than the Palaeozoic world it replaced. In this case, the severity of the shift may call for both a collapse in productivity of silica-secreting organisms and a set of conditions adverse to the preservation of bedded chert, perhaps including a low supply of dissolved silica to the oceans. As pointed by Kump et al. (2000), although the accumulation of biogenic silica is not a direct indicator of silica weathering intensity, it is a probable indicator of silica supply to the oceans. It is possible that one, of many, contributing factors to the ETCG may have been the uniformly warm and dry mega-monsoonal climate that prevailed throughout Pangea's interior in the Early Triassic (Parrish, 1993), which coupled with the lower topography of the now eroded Hercynian and Ural mountains, may have led to significantly less weathering than during the Permian.

Racki (1999) was puzzled over the absence of chert following the end-Permian extinction event especially since an increase in chert accumulation appears to have accompanied other extinction events such as the Cretaceous-Tertiary and the Frasnian-Fammenian events. As an alternate explanation, he offered the idea that the ETCG reflects the non-selective loss of silica-secreting fauna associated with the end-Permian extinction. Accordingly, Kozur (1998a,b) documented a substantial decline in the number of radiolarian families (nine to two), Demospongiae families (12 to five) and Hexactinellida families (six to one). The extinction of several families of siliceous sponges and radiolarians is undoubtedly significant and must have contributed to the ETCG as suggested by Racki (1999). However, while the diversity of siliceous organisms remained very low for most of the Early Triassic, these organisms staged a spectacular recovery starting in the latest Early Triassic and climaxing during the early Middle Triassic (Anisian). Interestingly, more than $50 \%$ of Middle Triassic siliceous sponge taxa are so-called Lazarus taxa that existed prior to the Late Permian decline (Kozur, 1998a,b). It appears that the negative environmental conditions that led to the demise of the PCE, and surely contributed to the extinction of siliceous biota, prevailed for millions of years, during which many silica-secreting organisms survived and reproduced in yet unknown refuges, patiently awaiting the return of a more hospitable marine environment. It took a staggering 8-10 Ma for the world oceans to fully recover from the end-Permian event.

\section{Conclusions}

A significant global event occurred at about the Sakmarian-Artinksian boundary that triggered a vigorous pattern of thermohaline circulation along the northwest margin of Pangea. This event followed the thawing of Gondwana ice sheets in the southern hemisphere and coincides with maximum flooding on global scale, cessation of cyclothem sedimentation and onset of widespread biogenic silica preservation (Permian Chert Event). Seasonal thawing of northern sea ice, the presumed engine of thermohaline circulation, led to the influx and circulation of dense, hypersaline cold water in the deep Panthalassan Ocean parallel to the northwest margin of Pangea, displacing nutrients- (phosphorus, iron, nitrogen, etc.) and silica-rich water in its path and forcing it along the oceanic margins via upwelling. Lighter melt water was also carried southward all along northwest Pangea through Coriolis forcing. This led to the contraction and ultimate disappearance of prolific warm-water carbonate factories and their replacement by biologically impoverished cool- to cold-water carbonate factories. This also led to 
the expansion of siliceous factories and preservation of their sedimentary products as bedded spiculitic chert, associated with unusually large phosphate and glauconite deposits. The areas favourable to siliceous sedimentation and preservation expanded both landward and southward during the Guadalupian and this process reached its zenith during the Lopingian, at which time not only northwest Pangea but many warmer areas of Panthalassa and the Tethys became the loci of sponge and radiolarian siliceous sedimentation. At that time, seasonal sea ice may have reached the latitudes of the Barents Sea and the Sverdrup Basin.

A major event occurred during latest Permian time which led to the collapse of thermohaline circulation. Presumably rapid global warming and equally rapid thawing of northern sea ice destroyed a palaeoceanographic setting that had promoted the growth and preservation of biogenic siliceous sediments for nearly $30 \mathrm{Ma}$. Complete thawing of northern sea ice would have ended thermohaline circulation and led to warm and sluggish oceanic conditions inimical to the production, accumulation and preservation of biogenic silica. These conditions lasted between 810 million yr (Early Triassic Chert Gap), during which several families of silica-secreting organisms became extinct, while others took refuge under more favourable conditions, before staging a come back during Anisian time (early Middle Triassic).

\section{Acknowledgements}

The authors are indebted to Noel James, Ashton Embry, Steve Grasby, Charles Henderson, Wayne Bamber, John Utting and Laura Gates for providing insightful comments on an earlier version of the manuscript and sharing ideas about the concepts presented here. The manuscript was also reviewed by Paul Wignall and Doug Erwin whose comments led to significant improvements. This contribution was built upon many years of field work in the Canadian Arctic, sponsored by the Geological Survey of Canada and the Polar Continental Shelf Project. The second author received also support from the Geological Museum in Lausanne and from the Swiss National Foundation (projects Nos 20-33448.92 and 2053787.98) for meetings in Calgary and fieldworks in Oman.

\section{References}

Alvarez, L.W., Alvarez, W., Asaro, F., Michel, H.V., 1980. Extraterrestrial cause for the Cretaceous-Tertiary extinction. Science 208, 1095-1108.

Baars, D.L., 1988. Triassic and older stratigraphy, Southern Rocky Mountains and Colorado Plateau, ch. 4. In: Sloss, L.L. (Ed.), Sedimentary Cover - North American Craton. The Geology of North America, vol. D-2. Geological Society of America, Boulder, CO, pp. 53-64.

Babcock, J.A., 1977. Calcareous algae, organic boundstones, and the genesis of the upper Capitan Limestone (Permian, Guadalupian), Guadalupe Mountains, west Texas and New Mexico. In: Hileman, M.E., Mazullo, S.J. (Eds.), Upper Guadalupian Facies, Permian Reef Complex, Guadalupe Mountains, New Mexico and west Texas. Permian Basin Section. SEPM Publication 77-6, pp. 3-44.

Bamber, E.W., Waterhouse, J.B., 1971. Carboniferous and Permian stratigraphy and paleontology, Northern Yukon Territory, Canada. Bull. Can. Pet. Geol. 19, 29-250.

Barron, E.J., Fawcett, P.J., 1995. The climate of Pangea: a review of climate model simulations of the Permian. In: Scholle, P.A., Peryt, T., Ulmer-Scholle, D.S. (Eds.), The Permian of Northern Pangea, vol. 2: Paleogeography, Paleoclimates, Stratigraphy. Springer, Heidelberg, pp. 37-52.

Baud, A., 2001. The new GSSP, base of the Triassic: some consequences. Albertiana 26, 5-7.

Baud, A., Jenny, C., Papanikolaou, D., Sideris, C., Stampfli, G., 1991. New observations on the Permian stratigraphy in Greece and geodynamic interpretation. Bull. Geol. Soc. Greece 25, 187-206.

Beauchamp, B., 1989. Lower Permian (Artinskian) spongebryozoan buildups, southwestern Ellesmere Island, Canadian Arctic Archipelago. In: Geldsetzer, H.H.J., James, N.P., Tebbutt, G.E. (Eds.), Reefs, Canada and Adjacent Areas. Can. Soc. Pet. Geol. Mem. 13, 575-584.

Beauchamp, B., 1993. Upper Paleozoic reefs of Sverdrup Basin, Canadian Arctic: an aid to Barents Sea exploration. In: Vorren, T.O., Bergsager, E., Dahl-Stamnes, Ø.A., Holter, E., Johansen, B., Lie, E., Lund, T.B. (Eds.), Arctic Geology and Petroleum Potential. Nor. Pet. Soc. Spec. Publ. 2, $217-$ 241.

Beauchamp, B., 1994. Permian climatic cooling in the Canadian Arctic. In: Klein, G.D. (Ed.), Pangea: Paleoclimate, Tectonics and Sedimentation during Accretion, Zenith and Break-up of a Super-Continent. Geol. Soc. Am. Spec. Pap. 288, 229-246.

Beauchamp, B., 1995. Permian history of Arctic North Amer- 
ica. In: Scholle, P.A., Peryt, T., Ulmer-Scholle, D.S. (Eds.), The Permian of Northern Pangea: Sedimentary Basins and Economic Resources, vol. 2. Springer, Heidelberg, pp. 3-22. Beauchamp, B., Davies, G.R., Nassichuk, W.W., 1989. Upper Carboniferous to Lower Permian Palaeoaplysina-phylloid algal buildups, Canadian Arctic Archipelago. In: Geldsetzer, H.H.J., James, N.P., Tebbutt, G.E. (Eds.), Reefs, Canada and Adjacent Areas. Can. Soc. Pet. Geol. Mem. 13, 590599.

Beauchamp, B., Desrochers, A., 1997. Permian warm- to very cold carbonates and cherts in northwest Pangea. In: James, N.P., Clarke, J. (Eds.), Cool Water Carbonates. SEPM Spec. Publ. 56, 327-347.

Beauchamp, B., Harrison, J.C., Henderson, C.M., 1989. Upper Paleozoic stratigraphy and basin analysis of the Sverdrup Basin, Canadian Arctic Archipelago, part 1 - Time frame and tectonic evolution. Curr. Res. Part G, Geol. Surv. Can. Pap. 89-1G, 105-113.

Beauchamp, B., Harrison, J.C., Henderson, C.M., 1989. Upper Paleozoic stratigraphy and basin analysis of the Sverdrup Basin, Canadian Arctic Archipelago, part 2 - Transgressive-regressive sequences: Curr. Res. Part G, Geol. Surv. Can. Pap. 89-1G, 115-124.

Beauchamp, B., Harrison, J.C., Utting, J., Brent, T.A., Pinard, S., 2001. Carboniferous and Permian subsurface stratigraphy, Prince Patrick Island, Northwest Territories. Can. Arctic Geol. Surv. Can. Bull. 565, 93 pp.

Beauchamp, B., Henderson, C.M., 1994. The Lower Permian Raanes. Great Bear Cape and Trappers Cove formations, Sverdrup Basin, Canadian Arctic: stratigraphy and conodont zonation. Bull. Can. Pet. Geol. 42, 562-597.

Beauchamp, B., Mayr, U., Harrison, J.C., Desrochers, A., 1995. Uppermost Permian stratigraphy (Unit P6), Hvitland Peninsula and adjacent areas, NW Ellesmere Island. Geol. Surv. Can. Curr. Res. 1995-B, 65-70.

Beauchamp, B., Sherry, C.T., Mayr, U., Harrison, J.C., Desrochers, A., 1995. Moscovian (Upper Carboniferous) to Sakmarian (Lower Permian) stratigraphy (Hare Fiord and Nansen formations; Unit C2), Hvitland Peninsula and adjacent areas, NW Ellesmere Island. Geol. Surv. Can. Curr. Res. 1995-B, 37-46.

Beauchamp, B., Thériault, P., 1994. Late paleozoic syn- and post-rift sequences on Grinnell peninsula, Canadian Arctic (Sverdrup Basin): evidence for basin margin tectonic disturbances associated with sequence boundaries. In: Embry, A.F., Beauchamp, B., Glass, D.J. (Eds), Pangea: Global Environments and Resources. Can. Soc. Pet. Geol. Mem. 17, 199-218.

Beauchamp, B., Thériault, P., Henderson, C.M., Pinard, P., Rui, L., 1998. Formations of the Sverdrup Basin, ch. VI. In: Mayr, U. et al. (Eds.), The Geology of Devon Island North of $76^{\circ}$, Canadian Arctic Archipelago. Geol. Surv. Can. Bull. 195-233.

Becker, L., Poreda, R.J., Hunt, A.G., Bunck, T.E., Rampino, M., 2001. Impact event at the Permian-Triassic boundary: Evidence from extraterrestrial noble gases in fullerenes. Science 291, 1530-1533.
Berner, R.A., 1990. Atmospheric carbon dioxide levels over Phanerozoic time. Science 249, 1382-1386.

Berner, R.A., 1991. A model for atmospheric $\mathrm{CO}_{2}$ over Phanerozoic time. Am. J. Sci. 291, 339-376.

Birkelund, T., Perch-Nielsen, K., 1976. Late Palaeozoic-Mesozoic evolution of central East Greenland. In: Escher, A., Stuart Watt, W. (Eds.), Geology of Greenland. Grønlands Geologiske Undersøgelse, Geological Survey of Greenland, pp. 305-339.

Blendinger, W., Bowlin, B., Zijp, F.R., Darke, G., Ekroll, M., 1997. Carbonate buildup flank deposits: an example from the Permian (Barents Sea, northern Norway) challenges classical facies models. Sediment. Geol. 112, 89-103.

Bowring, S.A., Erwin, D.H., Jin, Y.G., Martin, M.W., Davidek, K., Wang, W., 1998. U/Pb zircon geochronology and tempo of the end-Permian mass extinction. Science 280, 1039-1045.

Brandley, R.T., Krause, F.F., 1994. Thinolite-type pseudomorphs after ikaite: indicators of cold water on the subequatorial western margin of Lower Carboniferous North America. In: Embry, A.F., Beauchamp, B., Glass, D.J. (Eds.), Pangea: Global Environments and Resources. Can. Soc. Pet. Geol. Mem. 17, 333-344.

Brandley, R.T., Krause, F.F., 1997. Upwelling, thermoclines, and wave-sweeping on an equatorial carbonate ramp: Lower Carboniferous strata of Western Canada. In: James, N.P., Clarke, J. (Eds.), Cool Water Carbonates. SEPM Spec. Publ. 56, 365-390.

Breuninger, R.H., Canter, K.L., Isaacson, P.E., 1989. Pennsylvanian-Permian Palaeoaplysina and algal buildups, Snaky Canyon Formation, east-central Idaho, USA. In: Geldsetzer, H.H.J., James, N.P., Tebbutt, G.E. (Eds.), Reefs, Canada and Adjacent Areas. Can. Soc. Pet. Geol. Mem. 13, 631-637.

Bugge, T., Mangerud, G., Elvebakk, G., Mørk, A., Nilsson, I., Fanavoll, S., Vigran, J.O., 1995. The upper Paleozoic succession on the Finnmark Platform, Barents Sea. Nor. Geol. Tidsskr. 75, 3-30.

Bullivant, J.S., Dearborn, J.H., 1967. The fauna of the Ross Sea, part 5. Department of Scientific Industrial Research Bulletin 76, Wellinton, 76 pp.

Campbell, I.H., Czamanske, G.K., Fedorenko, V.A., Hill, R.I., Stepanov, V., 1992. Synchronism of the Siberian Traps and the Permian-Triassic Boundary. Science 258, 1760-1763.

Casey, R.E., 1993. Radiolaria. In: Lipps, J.H. (Ed.), Fossil Prokaryotes and Protists. Blackwell, Boston, MA, pp. 249-284.

Chuvashov, B.I., 1983. Permian reefs of the Urals. Facies 8, 191-212.

Cordey, F., 1998. Radiolaires des complexes d'accrétion de la Cordillère canadienne (Colombie-Britannique). Geol. Surv. Can. Bull. 509, 209 pp.

Cordey, F., Marcoux, J., Bucher, H., Girard, C., Lécuyer, C., Crasquin-Soleau, S., Baud, A., Orchard, M., 1999. Record of the Permo-Triassic Crisis in Oceanic Environments: New Targets in Oman, Nevada, and British Columbia, EUG 99. Terra Abstract, Strasbourg, p. 275. 
Crowder, R.K., 1990. Permian and Triassic sedimentation in the northeastern Brooks Range: deposition of the Sadlerochit Group. Am. Assoc. Pet. Geol. Bull. 74, 1351-1370.

Crowley, T.J., 1994. Pangean climates. In: Klein, G.D. (Ed.), Pangea: Paleoclimate, Tectonics and Sedimentation during Accretion, Zenith and Break-up of a Super-Continent. Geol. Soc. Am. Spec. Pap. 288, 25-39.

Davies, G.R., 1977. Turbidites, debris sheets and truncation structures in Upper Paleozoic deep water carbonates of the Sverdrup Basin, Arctic Archipelago. In: Cook, H.E., Enos, P. (Eds.), Deep-Water Carbonate Environments. Soc. Econ. Paleontol. Mineral. Spec. Publ. 25, 221-249.

Davies, G.R., Nassichuk, W.W., 1991. Submarine cements and fabrics in Carboniferous to Lower Permian, reefal, shelfmargin and slope carbonates, Northwestern Ellesmere Island, Canadian Arctic Archipelago. Geol. Surv. Can. Bull. 399, $77 \mathrm{pp}$.

Denison, R.E., Koepnick, R.B., 1995. Variation in ${ }^{87} \mathrm{Sr} /{ }^{86} \mathrm{Sr}$ of Permian seawater: an overview. In: Scholle, P.A., Peryt, T., Ulmer-Scholle, D.S. (Eds.), The Permian of Northern Pangea, vol. 1: Paleogeography, Paleoclimates, Stratigraphy. Springer, Heidelberg, pp. 124-132.

Desrochers, A., Beauchamp, B., 1995. Ufimian-Kazanian (Lower and Upper Permian) stratigraphy (Van Hauen and Degerböls formations). Hvitland Peninsula and adjacent areas, NW Ellesmere Island. Geol. Surv. Can. Curr. Res. 1995-B, 57-64.

Detterman, R.L., Reiser, H.N., Brosgé, W.P., Dutro, J.T., Jr., 1975. Post-Carboniferous stratigraphy, northeastern Alaska. U.S. Geol. Surv. Prof. Pap. 886, 46 pp.

Dickins, J.M., 1993. Climate of the Late Devonian to Triassic. Palaeogeogr. Palaeoclimatol. Palaeoecol. 100, 89-94.

Dickins, J.M., 1996. Problems of a Late Palaeozoic glaciation in Australia and subsequent climate in the Permian. Palaeogeogr. Palaeoclimatol. Palaeoecol. 125, 185-197.

Domack, E.W., 1988. Biogenic facies in the Antarctic glacimarine environment: basis for a glacimarine summary. Palaeogeogr. Palaeoclimatol. Palaeoecol. 63, 357-372.

Dutro, J.T., Jr., Silberling, N.J., 1988. Megafossils biostratigraphy of some deep test wells, national Petroleum Reserve in Alaska. In: Gryc, C. (Ed.), Geology and Exploration of the National Petroleum Reserve in Alaska, 1974 to 1982. U.S. Geol. Surv. Prof. Pap. 1399, 667-686.

Ehrenberg, S.N., Pickard, N.A., Svana, T.A., Nilsson, I., Davydov, V.I., 2000. Sequence stratigraphy of the inner Finnmark carbonate platform (Upper Carboniferous-Permian), Barents Sea - correlation between well 712836-1 and the shallow IKU cores. Nor. Geol. Tidsskr. 80, 129-162.

Ekart, D.D., Cerling, T.E., Montanez, I.P., Tabor, N.J., 1999. A 400 million year carbon isotope record of pedogenic carbonate: implications for paleoatmospheric carbon dioxide. Am. J. Sci. 299, 805-827.

Ekhlakov, Y.A., 1991. Gubakha Region. In: International Congress on the Permian System of the World, Perm, USSR, 1991. Guides to Geological Excursions, excursion II: Central Urals. Jointly published by Urals Branch,
USSR Academy of Sciences and Earth Sciences and Resources Institute, University of South Carolina, pp. 54-92.

Embry, A.F., 1991. Mesozoic history of the Arctic Islands, ch. 14. In: Trettin, H.P. (Ed.), Geology of the Innuitian Orogen and Arctic Platform of Canada and Greenland, Geology of Canada. Geol. Surv. Can. 3 (also The Geology of North America, Geol. Soc. Am. vol. E), 369-434.

Embry, A.F., 1993. Crockerland - The Northwest source area for the Sverdrup Basin, Canadian Arctic Islands. In: Vorren, T.O., Bergsager, E., Dahl-Stamnes, Ø.A., Holter, E., Johansen, B., Lie, E., Lund, T.B. (Eds.), Arctic Geology and Petroleum Potential. Nor. Pet. Soc. Spec. Publ. 2, 205-216.

Epshteyn, O.G., 1981. Late Permian ice-marine deposits of the Atkan Formation in the Kolyma River headwaters regions, U.S.S.R. In: Hambrey, M.J., Harland, W.B. (Eds.), Earth's Pre-Pleistocene Glacial Record. Cambridge University Press, Cambridge, pp. 270-273.

Erwin, D.H., 1993. The Great Paleozoic Crisis. Life and Death in the Permian. Columbia University Press, New York, 327 pp.

Erwin, D.H., 1994. The Permo-Triassic extinction. Nature 367, 231-236.

Erwin, D.H., 1995. The end-Permian mass extinction. In: Scholle, P.A., Peryt, T., Ulmer-Scholle, D.S. (Eds.), The Permian of Northern Pangea, vol. 1: Paleogeography, Paleoclimates, Stratigraphy. Springer, Heidelberg, pp. 20-34.

Ezaki, Y., Kawamura, T., Kawamura, K., 1994. Kapp Starostin Formation in Spitsbergen: a sedimentary and faunal record of Late Permian palaeoenvironments in an Arctic region. In: Embry, A.F., Beauchamp, B., Glass, D.J. (Eds.), Pangea: Global Environments and Resources. Can. Soc. Pet. Geol. Mem. 17, 647-656.

Fedorowski, J., Bamber, E.W., 2001. Guadalupian (Middle Permian) solitary rugose corals from the Degerböls and Trold Fiord formations, Ellesmere and Melville islands, Canadian Arctic Archipelago. Acta Geol. Pol. 51, 31-79.

Fedorowski, J., Bamber, E.W., Stevens, C.H., 1999. Permian corals of the Cordilleran-Arctic-Uralian realm. Acta Geol. Pol. 49, 159-173.

Flügel, E., 1981. Lower Permian Tubiphytes/Archaeolithoporella buildups in the southern Alps (Austria and Italy). In: Toomey, D.F. (Ed.), European Fossil Reef Models. SEPM Spec. Publ. 30, 143-160.

Flügel, E., Kochansky-Devidé, V., Ramovs, A., 1984. A Middle Permian calcisponge/algal/cement reef: Straza near Bled, Slovenia. Facies 10, 179-256.

Flügel, E., Reinhardt, J., 1989. Uppermost Permian reefs in Skyros (Greece) and Sichuan (China): implications for the Late Permian extinction event. Palaios 4, 502-518.

Frakes, L.A., Francis, J.E., Syktus, J.I., 1992. Climate Modes of the Phanerozoic: the History of the Earth's Climate Over the Past 600 Million Years. Cambridge University Press, Cambridge, 274 pp.

Francis, J.E., 1994. Palaeoclimates of Pangea - geological evidence. In: Embry, A.F., Beauchamp, B., Glass, D.J. (Eds.), 
Pangea: Global Environments and Resources. Can. Soc. Pet. Geol. Mem. 17, 265-274.

Froelich, P.N., Blanc, V., Mortlock, R.A., Chillrud, S.N., Dunstan, W., 1992. River fluxes of dissolved silica to the ocean were higher during glacials: $\mathrm{Ge} / \mathrm{Si}$ in diatoms, rivers and oceans. Paleoceanography 7, 739-767.

Gammon, P.R., James, N.P., Pisera, A., 2000. Eocene spiculites and spongiolites in southwestern Australia: Not deep, not polar, but shallow and warm. Geology 28, 855-858.

Gibson, D.W., 1993. Triassic, subchapter 4G. In: Stott, D.F., Aitken, J.D. (Eds.), Sedimentary Cover of the Craton in Canada, Geology of Canada. Geol. Surv. Can. 5, 294-320.

Golonka, J., Ford, D., 2000. Pangean (Late CarboniferousMiddle Jurassic) paleoenvironment and lithofacies. Palaeogeogr. Palaeoclimatol. Palaeoecol. 161, 1-34.

Golonka, J., Ross, M.I., Scotese, C.R., 1994. Phanerozoic paleogeographic and paleoclimatic modeling maps. In: Embry, A.F., Beauchamp, B., Glass, D.J. (Eds.), Pangea: Global Environments and Resources. Can. Soc. Petr. Geol. Mem. $17,1-48$.

Gruszczynski, M., Halas, S., Hoffman, A., Malkowski, K., 1989. A brachiopod calcite record of the oceanic carbon and oxygen isotope shifts at the Permian-Triassic transition. Nature 337, 64-68.

Harrison, K.G., 2000. Role of increased marine silica input on paleo- $p \mathrm{CO}_{2}$ levels. Paleoceanography $15,292-298$.

Hein, J.R., Parrish, J.T., 1987. Distribution of siliceous deposits in space and time. In: Hein, J.R. (Ed.), Siliceous Sedimentary Rock-Hosted Ores and Petroleum. Van Nostrand Reinhold, New York, pp. 10-57.

Henderson, C.M., Bamber, E.W., Richards, B.C., Higgins, A.C., McGugan, A., 1993. Permian, subchapter 4F. In: Stott, D.F., Aitken, J.D. (Eds.), Sedimentary Cover of the Craton in Canada, Geology of Canada. Geol. Surv. Can. 5, 272-293.

Henderson, C., Baud, A., 1997. Correlation of the PermianTriassic boundary in Arctic Canada and comparison with Meishan, China. In: Naiwen, W., Remane, J. (Eds.), Stratigraphy. Proceedings of the 30th IGC, Beijing. VSP, Utrecht, pp. 143-152.

Henderson, C.M., Mei, S., 2000. Preliminary cool water Permian conodont zonation in North Pangea: a review. Permophiles Newsl. Subcomm. Permian Stratigr. 36, 16-23.

Henrich, R., Hartmann, M., Reitner, J., Schäfer, P., Freiwald, A., Steinmetz, S., Dietrich, P., Thiede, J., 1992. Facies belts and communities of Arctic Vesterisbanken Seamount (Central Greenland Sea). Facies 27, 71-104.

Herring, J.R., 1995. Permian phosphorites: a paradox of phosphogenesis. In: Scholle, P.A., Peryt, T., Ulmer-Scholle, D.S. (Eds.), The Permian of Northern Pangea: Sedimentary Basins and Economic Resources, vol. 2. Springer, Heidelberg, pp. 292-312

Ishiga, H., Yamakita, S., 1993. Permian/Triassic boundary in pelagic sediments, Southwest Japan - an introduction. Bull. Geol. Surv. Jpn. 44, 419-423.

Isozaki, Y., 1994. Superanoxia across the Permo-Triassic boundary: Record in accreted deep-sea pelagic cherts in
Japan. In: Embry, A.F., Beauchamp, B., Glass, D.J. (Eds.), Pangea: Global Environments and Resources. Can. Soc. Pet. Geol. Mem. 13, 805-812.

Isozaki, Y., 1997. Permo-Triassic boundary superanoxia and stratified superocean: records from lost deep sea. Science 276, 235-238.

James, N.P., 1997. The cool-water carbonate depositional realm. In: James, N.P., Clarke, J. (Eds.), Cool Water Carbonates. SEPM Spec. Publ. 56, 1-22.

Jin, Y., Wardlaw, B.R., Glenister, B.F., Kotlyar, G.V., 1997. Permian chronostratigraphic subdivisions. Episodes 20, 1015.

Kaiho, K., Kajiwara, Y., Nakano, T., Miura, Y., Kawahata, H., Tazaki, K., Ueshima, M., Chen, Z., Shi, G.R., 2001. End-Permian catastrophe by a bolide impact: Evidence of a gigantic release of sulfur from the mantle. Geology 29, 815-818.

Kajiwara, Y., Yamakita, S., Ishida, K., Ishiga, H., Imai, A., 1994. Development of a largely anoxic stratified ocean and its temporary massive mixing at the Permian/Triassic boundary supported by the sulfur isotopic record. Palaeogeogr. Palaeoclimatol. Palaeoecol. 111, 367-379.

Kakuwa, Y., 1996. Permian-Triassic mass extinction event recorded in bedded chert sequences in southwest Japan. Palaeogeogr. Palaeoclimatol. Palaeoecol. 121, 35-51.

Keith, M.L., 1982. Violent volcanism, stagnant oceans and some inferences regarding petroleum, strata-bound ores and mass extinctions. Geochim. Cosmochim. Acta 46, 2621-2637.

Kiersnowski, H., Paul, J., Peryt, T.M., Smith, D.B., 1995. Facies, paleogeography and sedimentary history of the southern Permian Basin in Europe. In: Scholle, P.A., Peryt, T., Ulmer-Scholle, D.S. (Eds.), The Permian of Northern Pangea: Sedimentary Basins and Economic Resources, vol. 2. Springer, Heidelberg, pp. 119-136.

Knoll, A.H., Bambach, R.K., Canfield, D.E., Grotzonger, J.P., 1996. Comparative Earth history and Late Permian mass extinction. Science 273, 452-457.

Kozur, H.W., 1998a. Some aspects of the Permian-Triassic boundary (PTB) and the possible causes for the biotic crises around this boundary. Palaeogeogr. Palaeoclimatol. Palaeoecol. 143, 227-272.

Kozur, H.W., 1998b. Problems for evaluation of the scenario of the Permian-Triassic boundary biotic crisis and of its cause. Geol. Croat. 51, 135-162.

Kump, L.R., Brantley, S.L., Arthur, M.A., 2000. Chemical weathering, atmospheric $\mathrm{CO}_{2}$, and climate. Annu. Rev. Earth Planet. Sci. 28, 611-667.

Laschet, C., 1984. On the origin of cherts. Facies 10, 257-289.

Lees, A., 1975. Possible influence of salinity and temperature on modern shelf carbonate sedimentation. Mar. Geol. 19, 159-198.

Lees, A., Buller, A.T., 1972. Modern temperate-water and warm-water shelf carbonate sediments contrasted. Mar. Geol. 13, M67-M73.

Mahoney, J.B., Link, P.K., Burton, B.R., Geslin, J.K., O’Brien, J.P., 1991. Pennsylvanian and Permian Sun Valley 
Group, Wood River Basin, South-Central Idaho. In: Cooper, J.D., Stevens, C.H. (Eds.), Paleozoic Paleogeography of the Western United States - II. The Pacific Section Society of Economic Paleontologists and Mineralogists, Los Angeles, CA, pp. 551-580.

Maliva, R.G., Knoll, A.H., Siever, R., 1990. Secular change in chert distribution: a reflection of evolving biological participation in the silica cycle. Palaios 4, 519-532.

Marcoux, J., Baud, A., 1986. The Permo-Triassic boundary in the Antalya nappes (Western Taurides, Turkey). Mem. Soc. Geol. Ital. 34, 243-252.

Martin, E.E., Macdougall, J.D., 1995. Sr and $\mathrm{Nd}$ isotopes at the Permian/Triassic boundary: A record of climate change. Chem. Geol. 125, 73-99.

McGowran, B., 1989. Silica burb in the Eocene ocean. Geology $17,857-860$.

Mei, S., Henderson, C.M., 2001. Evolution of Permian conodont provincialism and its significance in global correlation and paleoclimate implication. Palaeogeogr. Palaeoclimatol. Palaeoecol. 170, 237-260.

Menning, M., 1995. A numerical time scale for the Permian and Triassic Periods. In: Scholle, P.A., Peryt, T., UlmerScholle, D.S. (Eds.), The Permian of Northern Pangea, vol. 1: Paleogeography, Paleoclimates, Stratigraphy. Springer, Heidelberg, pp. 77-97.

Moore, T.E., Wallace, W.K., Bird, K.J., Karl, S.M., Mull, C.G., Dillon, J.T., 1994. Geology of Northern Alaska. In: Plafker, G., Berg, H.C. (Eds.), The Geology of Alaska, The Geology of North America. Geol. Soc. Am, vol. G-1, 49-140.

Mørk, A., Embry, A.F., Weitschat, W., 1989. Triassic transgressive-regressive cycles in the Sverdrup Basin and the Barents Sea. In: Collinson, J.D. (Ed.), Correlation in Hydrocarbon Exploration. Graham and Trotman, London, pp. 113-130.

Murchey, B.L., Jones, D.L., 1992. A mid-Permian chert event: widespread deposition of biogenic siliceous sediments in coastal, island arc and oceanic basins. Palaeogeogr. Palaeoclimatol. Palaeoecol. 96, 161-174.

Murchey, B.L., Jones, D.L., Holdsworth, B.K., Wardlaw, B.R., 1988. Chapter 32. Distribution patterns of facies, radiolarians, and conodonts in the Mississippian to Jurassic siliceous rocks of the northern Brooks Range, Alaska. In: Gryc, G. (Ed.), Geology and Exploration of the National Petroleum Reserve in Alaska, 1974 to 1982. U.S. Geol. Surv. Prof. Pap. 1399, 697-724.

Mytton, J.W., Morgan, W.A., Wardlaw, B.R., 1983. Stratigraphic relations of Permian units, Cassia Mountains, Idaho. Geol. Soc. Am. Mem. 157, 281-303.

Nakrem, H.A., Mørk, A., 1991. New early Triassic Bryozoa (Trepostomata) from Spitsbergen, with some remarks on the stratigraphy of the investigated horizons. Geol. Mag. 128, 129-140.

Nassichuk, W.W., 1995. Permian ammonoids in the Arctic regions of the world: In: Scholle, P.A., Peryt, T., UlmerScholle, D.S. (Eds.), The Permian of Northern Pangea, vol. 1: Paleogeography, Paleoclimates, Stratigraphy. Springer, Heidelberg, pp. 210-235.
Nassichuk, W.W., Thorsteinsson, R., Tozer, E.T., 1973. Permian-Triassic boundary in the Canadian Arctic Archipelago. In: Logan, A., Hills, L.V. (Eds.), The Permian and Triassic Systems and Their Mutual Boundary. Can. Soc. Pet. Geol. Mem. 2, 286-293.

Nassichuk, W.W., Wilde, G.L., 1977. Permian fusulinaceans and stratigraphy at Blind Fiord, southwestern Ellesmere Island. Geol. Surv. Can. Bull. 268, 59 pp.

Nelson, D.M., Tréguer, P., Brzezinski, M.A., Leynaert, A., Quéguiner, B., 1995. Production and dissolution of biogenic silica in the ocean - revised global estimates, comparison with regional data and relationship to biogenic sedimentation. Glob. Biogeochem. Cycle 9, 359-372.

Ogg, J.G., Steiner, M.B., 1991. Early Triassic magnetic polarity time scale - integration of magnetostratigraphy, ammonite zonation and sequence stratigraphy for stratotype sections (Canadian Arctic Archipelago). Earth Planet. Sci. Lett. 107, 69-89.

Ozhgibesov, V.P., Sofronitsky, P.A., Dorofeyev, Y.P., 1991. Kungur Region. In: International Congress on the Permain System of the World, Perm, USSR, 1991, Guides to Geological Excursions, excursion II: Central Urals. Jointly published by Urals Branch, USSR Academy of Sciences, Earth Sciences and Resources Institute, University of South Carolina, pp. 20-51.

Parrish, J.T., 1993. Climate of the Supercontinent Pangea. J. Geol. 101, 215-233.

Pattison, J., Stemmerik, L., 1996. Upper Permian foraminifera from East Greenland. Grønl. Geol. Unders. Bull. 171, 7390.

Pinet, P.R., 1992. Oceanography, an Introduction to the Planet Oceanus. West Publishing Co., St. Paul, MN, 572 pp.

Pole, F.G., Sandberg, C.A., 1991. Mississippian paleogeography and conodont biostratigraphy of the Western United States. In: Cooper, J.D., Stevens, C.H. (Eds.), Paleozoic Paleogeography of the Western United States - II. The Pacific Section Society of Economic Paleontologists and Mineralogists, Los Angeles, CA, pp. 107-136.

Racki, G., 1999. Silica-secreting biota and mass extinctions: survival patterns and processes. Palaeogeogr. Palaeoclimatol. Palaeoecol. 154, 107-132.

Rees, P.A., Gibbs, M.T., Ziegler, A.M., Kutzbach, J.E., Behling, P.T., 1999. Permian climates: Evaluating model predictions using global paleobotanical data. Geology 27, 891894.

Reid, S.K., Dorobek, S.L., 1991. Development of third- and fourth-order depositional sequences in the Lower Mississippian Mission Canyon Formation and stratigraphic equivalents, Idaho and Montana. In: Cooper, J.D., Stevens, C.H. (Eds.), Paleozoic Paleogeography of the Western United States - II. The Pacific Section Society of Economic Paleontologists and Mineralogists, Los Angeles, CA, pp. 527-542.

Renne, P.R., Zichao, Z., Richards, M.A., Black, M.T., Basu, A.R., 1995. Synchrony and causal relations between Permian-Triassic boundary crises and Siberian Flood Volcanism. Science 269, 1413-1416.

Retallack, G.J., 1999. Postapocalyptic greenhouse paleoclimate 
revealed by earliest Triassic paleosols in the Sydney Basin, Australia. Geol. Soc. Am. Bull. 111, 52-70.

Retallack, G.J., Seyedolali, A., Krull, E.S., Holser, W.T., Ambers, C.P., Kyte, F.T., 1998. Search for evidence of impact at the Permian-Triassic boundary in Antarctica and Australia. Geology 26, 979-982.

Richards, B.C., Bamber, E.W., Higgins, A.C., Utting, J., 1993. Carboniferous, subchapter 4E. In: Stott, D.F., Aitken, J.D. (Eds.) Sedimentary Cover of the Craton in Canada, Geology of Canada. Geol. Surv. Can. 5, 202-271.

Richards, B.C., Bamber, E.W., Utting, J., 1997. Upper Devonian to Permian, ch. 8. In: Norris, D.K. (Ed.), The Geology, Mineral and Hydrocarbon Potential of Northern Yukon Territory and Northwestern District of Mackenzie. Geol. Surv. Can. Bull. 422, 201-251.

Ritter, S.M., Morris, T.H., 1997. Oldest and lowest latitudinal occurrence of Palaeoaplysina: Middle Pennsylvanian Ely Limestone, Burbank Hills, Utah. Palaios 12, 397-401.

Ruddiman, W.F., Prell, W.L., 1997. Introduction to the upliftclimate connection, ch. 1. In: Ruddiman, W.F. (Ed.), Tectonic Uplift and Climate Change. Plenum Press, New York, pp. 3-19.

Scholle, P.A., Stemmerik, L., Ulmer, D.S., 1991. Diagenetic history and hydrocarbon potential of Upper Permian carbonate buildups, Wegener Halvø Area, Jameson Land Basin, East Greenland. Am. Assoc. Pet. Geol. Bull. 75, 701725.

Scotese, C.R., Langford, R.P., 1995. Pangea and the paleogeography of the Permian. In: Scholle, P.A., Peryt, T., UlmerScholle, D.S. (Eds.), The Permian of Northern Pangea, vol. 1: Paleogeography, Paleoclimates, Stratigraphy. Springer, Heidelberg, pp. 3-19.

Smith, D.B., 1981. The magnesian Limestone (Upper Permian) reef complex of northeastern England. In: Toomey, D.F. (Ed.), European Fossil Reef Models. SEPM Spec. Publ. 30, 161-186.

Smith, D.B., 1981. Bryozoan-algal patch reefs in the Upper Permian Lower Magnesian Limestone of Yorkshire, northeast England. In: Toomey, D.F. (Ed.), European Fossil Reef Models. SEPM Spec. Publ. 30, 187-202.

Stanley, S.M., 1984. Marine mass extinctions: a dominant role for temperature. In: Nitecki, M.H. (Ed.), Extinctions. University of Chicago Press, Chicago, IL, pp. 69-117.

Stanley, S.M., 1988. Paleozoic mass extinctions: shared patterns suggest global cooling as a common cause. Am. J. Sci. 288, 334-352.

Stemmerik, L., 1997. Permian (Artinskian-Kazanian) coolwater carbonates in Greenland, Svalbard and the Western Barents Sea. In: James, N.P., Clarke, J. (Eds.), Cool Water Carbonates. SEPM Spec. Publ. 56, 349-364.

Stemmerik, L., 2000. Late Palaeozoic evolution of the North Atlantic margin of Pangea. Palaeogeogr. Palaeoclimatol. Palaeoecol. 161, 95-126.

Stemmerik, L., Håkansson, E., 1989. Stratigraphy and depositional history of the Upper Paleozoic and Triassic sediments in the Wandel Sea Basin, central and eastern North Greenland. Rapp. Grønl. Geol. Unders. 143, 21-45.
Stemmerik, L., Nilsson, I., Elvebakk, G., 1995. Gzhelian-Asselian depositional sequences in the western Barents Sea and North Greenland. In: Steel, R.J., Felt, V.L., Johannessen, E.P., Mathieu, C. (Eds.), Sequence Stratigraphy of the Northwest European Margin. Nor. Pet. Soc. Spec. Publ. 5, 529-544.

Stemmerik, L., Worsley, D., 1989. Late Palaeozoic sequence correlations, North Greenland, Svalbard and the Barents Shelf. In: Collinson, J.D. (Ed.), Correlation in Hydrocarbon Exploration. Graham and Trotman, Norwegian Petroleum Society, London, pp. 99-111.

Stemmerik, L., Worsley, D., 1995. Permian history of the Barents Shelf area. In: Scholle, P.A., Peryt, T., UlmerScholle, D.S. (Eds.), The Permian of Northern Pangea: Sedimentary Basins and Economic Resources, vol. 2. Springer, Heidelberg, pp. 98-118.

Stevens, C.H., 1982. The Early Permian Thysanophyllum coral belt: another clue to Permian plate-tectonic reconstructions. Geol. Soc. Am. Bull. 93, 798-803.

Surlyk, F., Hurst, J.M., Piasecki, S., Rolle, F., Scholle, P.A., Stemmerik, L., Thomsen, E., 1986. The Permian of the western margin of the Greenland Sea - a future exploration target. In: Halbouty, M.T. (Ed.), Future Petroleum Provinces of the World. Am. Assoc. Pet. Geol. Mem. 40, 629-660.

Suzuki, N., Ishida, K., Shinomiya, Y., Ishiga, H., 1998. High productivity in the earliest Triassic ocean: black shales, Southwest Japan. Palaeogeogr. Palaeoclimatol. Palaeoecol. 141, 53-65.

Thériault, P., Desrochers, A., 1994. Late Carboniferous calcrete development in the Canadian Arctic: evidence for a semi-arid climate in northwestern Pangea. In: Embry, A.F., Beauchamp, B., Glass, D.J. (Eds.), Pangea: Global Environments and Resources. Can. Soc. Pet. Geol. Mem. 17, 319-332.

Thorsteinsson, R., 1974. Carboniferous and Permian stratigraphy of Axel Heiberg Island and western Ellesmere Island, Canadian Arctic Archipelago. Geol. Surv. Can. Bull. 224, $115 \mathrm{pp}$.

Tozer, E.T., 1967. A standard for Triassic time. Geol. Surv. Can. Bull. 156, 103 pp.

Treguer, P., Nelson, A.J., Van Bennekom, D.J., Leynaert, A., Queguiner, B., 1995. The silica balance in the world ocean: A reestimate. Science 268, 375-379.

Ustritsky, V.I., 1973. Permian climate. In: Logan, A., Hills, L.V. (Eds.), The Permian and Triassic Systems and Their Mutual Boundary. Can. Soc. Pet. Geol. Mem. 2, 733-744.

Utting, J., 1994. Palynostratigraphy of Permian and Lower Triassic rocks, Sverdrup Basin, Canadian Arctic Archipelago. Geol. Surv. Can. Bull. 478, 107 pp.

Utting, J., 2001. Permian and Early Triassic palynomorph assemblages from Canadian Arctic Archipelago, Alaska, Greenland, and Arctic Europe. Natura Bresciana. Ann. Mus. Civ. Sci. Nat. Monogr. 25, 327-340.

Van Wagoner, N.A., Mudie, P.J., Cole, F.E., Daborn, G., 1989. Siliceous sponge communities, biological zonation, and recent sea-level change on the Arctic margin: Ice Island results. Can. J. Earth Sci. 26, 2341-2355. 
Vennin, E., 1997. Architecture sédimentaire des bioconstructions Permo-Carbonifères de l'Oural Méridional (Russie). Publication - Société géologique du Nord, vol. 27. Villeneuve d'Ascq, $350 \mathrm{pp}$.

Visser, J.N.J., 1995. Post-glacial Permian stratigraphy and geography of southern and central Africa: boundary conditions for climatic modelling. Palaeogeogr. Palaeoclimatol. Palaeoecol. 118, 213-243.

Wahlman, G.P., 1985. Lower Permian (Wolfcampian) Archaeolithoporella-Tubiphytes-sponge boundstones from the subsurface of West Texas. In: Toomey, D.F., Nitecki, M.H. (Eds.), Paleoecology, Contemporary Research and Applications. Springer, Berlin, pp. 208-215.

Wahlman, G.P., 1988. Subsurface Wolfcampian (Lower permian) shelf-margin reefs in the Permian basin of west Texas and southeastern New Mexico. In: Morgan, W.P., Babcock, J.A. (Eds.), The Permian of the Midcontinent. SEPM Midcont. Sect. Spec. Publ. 1, 177-204.

Wahlman, G.P., in press. Upper Carboniferous-Lower Permian (Bashkirian-Kungurian) reefs. In: Flügel, E., Kiessling, W. (Eds.), Phanerozoic Reef Patterns. SEPM Spec. Publ.

Wahlman, G.P., Konovalova, M.V., in press. Upper Carboniferous-Lower Permian Kozhim carbonate bank, Subpolar Pre-Ural Mountains, northern Russia. In: Zempolich, W.G., Cook, H.E. (Eds.), Carbonate Reservoirs and Field Analogs of the CIS. SEPM Spec. Publ.

Wang, K., Geldzetser, H.H., Krouse, H.R., 1994. PermianTriassic extinction: organic $\delta^{13} \mathrm{C}$ evidence from British Columbia, Canada. Geology 22, 580-584.

Wardlaw, B.R., 1980. Middle-Late Permian paleogeography of Idaho, Nevada, Montana, Utah and Wyoming. In: Fouchg, T.D., Magathan, E.R. (Eds.), Paleozoic Paleogeography of West-central United States. West-central United States Paleogeography Symposium, SEPM Rocky Mountain Section, vol. 1, pp. 352-361.

Wardlaw, B.R., Collinson, J.W., 1986. Paleontology and deposition of the Phosphoria Formation. Contrib. Geol. Univ. Wyoming 24, 107-142.

Wardlaw, B.R., Snyder, W.S., Spinosa, C., Gallegos, D.M.,
1995. Permian of the Western United States. In: Scholle, P.A., Peryt, T., Ulmer-Scholle, D.S. (Eds.), The Permian of Northern Pangea: Sedimentary Basins and Economic Resources, vol. 2. Springer, Heidelberg, pp. 23-40.

Wignall, P.B., Hallam, T., 1992. Anoxia as a cause of the Permian-Triassic mass extinction: facies evidence from northern Italy and the western United States. Palaeogeogr. Palaeoclimatol. Palaeoecol. 93, 21-46.

Wignall, P.B., Morante, R., Newton, R., 1998. The PermoTriassic transition in Spitsbergen: $\delta^{13} \mathrm{C}_{\text {org }}$ chemostratigraphy, $\mathrm{Fe}$ and $\mathrm{S}$ geochemistry, facies, fauna and trace fossils. Geol. Mag. 135, 47-62.

Wignall, P.B., Twitchett, R.J., 1996. Oceanic anoxia and the end Permian mass extinction. Science 272, 1155-1158.

Wilde, P., Quinby-Hunt, M., Berry, W.B.N., 1990. Vertical advection from oxic or anoxic water from the main pycocline as a cause of rapid extinction or rapid radiations. Lect. Notes Earth Sci. 30, 85-98.

Xu, D., Ma, S., Chai, Z., Sun, X., Zhang, Y., Yang, Z., 1985. Abundance variation of iridium and trace elements at the Permian/Triassic boundary at Shagsi in China. Nature 314, 154-156.

Xu, D., Yan, D., 1993. Carbon isotope and iridium event marker near the Permian-Triassic boundary in the Mesichan Section, Zhjiang Province, China. Palaeogeogr. Palaeoclimatol. Palaeoecol. 104, 171-176.

Yin, H., Zhang, K., Tong, J., Yang, Z., Wu, S., 2001. The Global Stratotype Section and Point (GSSP) of the Permian-Triassic Boundary. Episodes 24, 102-114.

Zhemchugova, V.A., Schamel, S., 1994. Carboniferous-Lower Permian carbonate reservoirs of the Timan-Pechora Basin. Int. Geol. Rev. 36, 15-23.

Ziegler, A.M., Gibbs, M.T., Hulver, M.L., 1998. A mini-atlas of oceanic water masses in the Permian Period. Proc. R. Soc. Victoria 110, 323-343.

Ziegler, A.M., Hulver, M.L., Rowley, D.B., 1997. Permian world topography and climate. In: Martini, I.P. (Ed.), Late Glacial and Postglacial Environmental Changes. Oxford University Press, New York, pp. 111-146. 